\title{
FINANCIAL SECTOR ASSESSMENT
}

\section{REPUBLIC OF TAJIKISTAN}

\section{MAY 2015}

\author{
FinanCE ANd Markets Global Practice \\ Europe And Central Asia Regional Vice Presidency
}

\begin{abstract}
A joint IMF-World Bank team visited the Republic of Tajikistan during January 27-February 9, 2015 to conduct an assessment under the Financial Sector Assessment Program (FSAP) Update. Based on information provided by the authorities and collected during the visits, the mission evaluated financial sector risks and vulnerabilities, the regulatory and supervisory framework, crisis management and safety nets, governance arrangements, access to finance, and insurance sector development.
\end{abstract}

The team comprised Martin Melecky (Head, World Bank), David Grigorian (Head, IMF), Hong Wang (Deputy, IMF), Jan Nolte, Maria Teresa Chimienti, Fredesvinda Fatima Montes, Adolfo Rouillon, Andrej Popovic, Raquel Letelier, and Peter Wrede (all World Bank), Suchitra Kumarapathy, Maxym Kryshko (all IMF); and Andras Fekete Gyor and Jan Willem van der Vossen (both external experts). 



\section{CONTENTS}

GLOSSARY

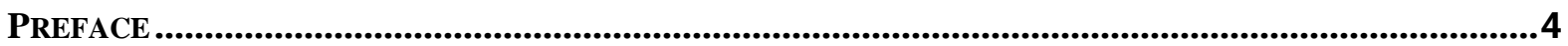

I. MACROECONOMIC ENVIRONMENT AND FINANCIAL SECTOR OVERVIEW ........8

A. Macroeconomic Background and Outlook ___ 8

B. Financial Sector Structure____ 9

C. Progress with 2007 FSAP Recommendations ___ 12

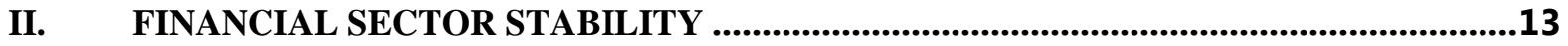

A. Key Macro-Financial Risks and Vulnerabilities___ 13

B. Banking Sector Vulnerabilities ___ 14

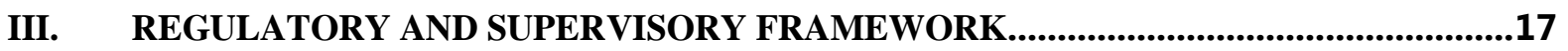

A. Microprudential Oversight ___ 17

B. Macroprudential Oversight____ 18

C. Anti-Money Laundering and Combating the Financing of Terrorism ___ 19

IV. CRISIS PREVENTION AND MANAGEMENT FRAMEWORK ..................................20

A. Emergency Liquidity Assistance ___ 20

B. Regime of Prompt Corrective Actions ___ 21

C. Bank Resolution Framework ___ 22

D. Deposit Insurance ___ 23

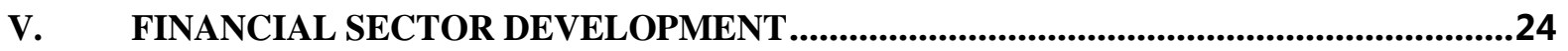

A. Credit Reporting Systems___ 24

B. Insolvency and Credit Rights___ 27

C. Payment and Settlement Systems ___ 30

D. Financial Inclusion __ 33

E. Insurance Market ___ 37

\section{FIGURES}

1. Macroeconomic Developments___ 41

2. Macroeconomic Vulnerabilities___ 42

3. Private Credit and Money Aggregates ___ 43

4. Bank Loans and NPLs Concentration by Economic Sector ___ 44

5. Interest Rates and Spreads __ 45 


\section{TABLES}

1. FSAP Update Main Recommendations

2. Financial System Structure, 2012-2014

3. Status of 2007 FSAP Main Recommendations 44

4. Selected Economic Indicators, 2011-2020 48

5. Financial Soundness Indicators, 2010-14 1/ 


\section{GLOSSARY}

\begin{tabular}{|c|c|}
\hline AML/CTF & Anti-money Laundering/Combating of the Financing of Terrorism \\
\hline $\mathrm{ADB}$ & Asian Development Bank \\
\hline AIB & Agroinvestbank \\
\hline BSD & Banking Supervision Department \\
\hline CAMEL & Capital, Assets, Management, Earnings, Liquidity \\
\hline CAR & Capital Adequacy Ratio \\
\hline CCA & Caucasus and Central Asia \\
\hline CDD & Customer Due Diligence \\
\hline CRS & Credit Reporting Systems \\
\hline DIF & Deposit Insurance Fund \\
\hline FATF & Financial Action Task Force \\
\hline FCP & Financial Consumer Protection \\
\hline FDE & Fund for Development of Entrepreneurship \\
\hline FIU & Financial Intelligence Unit \\
\hline FMD & Financial Monitoring Department \\
\hline FSAP & Financial Sector Assessment Program \\
\hline FSD & Financial Stability Department \\
\hline GoT & Government of Tajikistan \\
\hline ICAAP & Internal Capital Adequacy Assessment Process \\
\hline ICPs & Insurance Core Principles \\
\hline IFRS & International Financial Reporting Standards \\
\hline IMF & International Monetary Fund \\
\hline IT & Information Technology \\
\hline KYC & Know Your Customer \\
\hline LBA & Law on Banking Activity \\
\hline LNBT & Law on the National Bank of Tajikistan \\
\hline MCM & Monetary and Capital Markets Department of the IMF \\
\hline MCOs & Microcredit Organizations \\
\hline MDO & Microcredit Deposit Organization \\
\hline MFIs & Microfinance institutions \\
\hline $\mathrm{MoF}$ & Ministry of Finance \\
\hline MPD & Monetary Policy Department \\
\hline NBT & National Bank of Tajikistan \\
\hline NPL & Nonperforming Loan \\
\hline ROA & Return on Assets \\
\hline ROE & Return on Equity \\
\hline SIFIs & Systemically Important Financial Institutions \\
\hline SISS & State Insurance Supervisory Service \\
\hline SMRA & State Material Reserve Agency \\
\hline SOEs & State Owned Enterprises \\
\hline UBPR & Universal Bank Performance Report \\
\hline USD & U.S. Dollar \\
\hline
\end{tabular}




\section{Preface}

The mission met with the Ministry of Finance (MOF), the National Bank of Tajikistan (NBT), Deposit Insurance Fund (DIS), State Insurance Supervisory Service (SISS), commercial banks, and insurance companies.

The previous FSAP took place in 2007. The status of implementation of its Key Recommendations can be found in Table 1. The financial sector assessment is complemented by technical notes on (1) Banking Sector Vulnerabilities and Stress Testing; (2) Banking Supervision and Regulatory Framework; (3) Crisis Management, Bank Resolution, and Safety Nets; (4) Insurance Sector Developments; (5) Financial market infrastructure, and (7) Financial inclusion.

The team would like to convey its sincere appreciation to the Tajikistan authorities and other counterparts for their hospitality and generous support in facilitating its work. 


\section{EXECUTIVE SUMMARY}

Tajikistan's economy is entering a downturn and the banking sector is showing substantial weaknesses. As GDP growth is projected to slow down significantly in 2015 and beyond, several large banks appear vulnerable. System-wide nonperforming loans (NPLs) nearly doubled in 2014 and capital buffers are likely to be overstated due to misclassification and underprovisioning of bad loans. Credit quality is poor, owing to directed and related-party lending in the past, but also due to inadequate credit assessment methodologies and insufficient credit information. Against this background, the economy and the financial sector are facing the downside risks and negative spillovers from (i) a protracted period of negative growth in Russia, coupled with a possible slowdown of growth in China; (ii) commodity (especially cotton and aluminum) price shocks; and (iii) delays in structural reforms, particularly in banks and state-owned enterprises (SOEs). Stress tests confirm the presence of significant vulnerabilities in the banking sector. Large banks in Tajikistan are vulnerable, as one bank is insolvent and another one fails to meet the prudential requirements.

Although regulation has improved in line with recommendations of the 2007 FSAP, supervision and enforcement have been lagging behind. Further strengthening of the reporting and oversight framework is needed, along with the enforcement of corporate governance rules to minimize abuse by entrenched interests. The current condition characterized by weak large banks comes at a cost of low lending, credit resource misallocation, and serious moral hazard.

The widespread solvency problems in the sector must be addressed head-on and the authorities should be jointly prepared to cope with the worst. In this regard, adequate political and operational independence of the NBT is key to achieve proactive and timely enforcement of prudential supervision. ${ }^{1}$ Setting up a coordination body that brings together key policy stakeholders for contingency planning, and crisis management and resolution is crucial. The current framework for Prompt Corrective Actions is weak, lacks powers and incentives for the regulator to take timely resolution actions, and fails to promote accountability. Similarly, the legal framework for resolution of problem banks does not equip the authorities with an adequate range of powers and tools that could help resolve banks promptly. Deposit insurance does not yet fulfill its function of boosting the trust of the population in deposit-taking institutions and aiding greater mobilization of savings. The coverage limit is too low, micro and small enterprises are not covered by the insurance, and the payout procedures are surrounded by legal uncertainty and need to be based on technology rather than manual processes.

To fully realize the potential of its financial infrastructure in support of financial stability, efficiency, and inclusion, Tajikistan needs to implement further reforms:

- The private credit reporting system draws on data sourced from banks and microfinance institutions but fails to exploit other useful data such as telecommunication companies,

\footnotetext{
${ }^{1}$ See the FSAP Technical Note on Banking Regulation and Supervision on more detail assessment of NBT's supervisory independence.
} 
utilities and insurance companies to evaluate the creditworthiness of individuals with greater efficiency. Also, NBT does not have a credit registry to support their supervisory function.

- Enforcement of immovable collateral could benefit from improved out-of-court enforcement and credit collection through auction sales, which is quite ineffective. The legal framework governing pledges over movable assets must be urgently improved along with the Pledge Registry, which is weak and barely used by lenders.

- Although the payment settlement system is rudimentary and reliable, there are still risks that need to be mitigated and properly managed. To achieve greater use of non-cash payments, greater efforts are needed to stimulate both demand and supply of non-cash instruments and capture a greater share of the remittance market. The oversight function for payment systems needs to be strengthened and broadened in scope.

Advancing financial inclusion remains a major challenge for Tajikistan. Greater penetration of payment services, especially targeted at the remittance market, could be a promising avenue to promote the use of, ultimately, a range of financial services. While the microfinance sector appears to be more effective than banks in reaching out to financially underserved population, it faces constraints of lacking longer-term funding in local currency. The leasing sector could be a major player in boosting access to credit for those without collateral but the sector is underdeveloped. Any financial sector support programs need to be properly designed and carefully implemented to avoid market distortions and ensure sustainability. The insurance market is underdeveloped and hindered by state monopoly in major insurance products and weak regulatory and supervisory framework. For responsible delivery of all financial services, operationalizing the NBT's mandate for financial consumer protection (FCP) should be the immediate priority. In this respect, the NBT mandate on FCP in banking services can be usefully extended to all financial services.

As the current Banking Sector Development Strategy is ending, the main stakeholders in financial policy should develop a comprehensive strategy that addresses issues in achieving greater financial stability, efficiency, and inclusion in Tajikistan. 
Table 1. Tajikistan: FSAP Update Main Recommendations

\begin{tabular}{|c|c|c|}
\hline Recommendations and Authority Responsible for Implementation & Priority & Timeframe \\
\hline \multicolumn{3}{|l|}{ Microprudential Regulation, Supervision, and Enforcement } \\
\hline $\begin{array}{l}\text { Conduct thematic inspection (cross-sectional audit) of banks on credit risk } \\
\text { management to benchmark under-provisioning and capital short-falls; and take } \\
\text { enforcement actions to restore the soundness of problem banks }\end{array}$ & High & Immediate \\
\hline $\begin{array}{l}\text { Enforce proper loan loss provisioning and stop loan evergreening; use all legal } \\
\text { means to enforce loan contracts and restructure NPLs; write off non-collectible } \\
\text { debts; require banks to prepare ICAAPs and increase capital as needed (NBT). }\end{array}$ & High & Near term \\
\hline \multicolumn{3}{|l|}{ Financial Stability and Macroprudential Surveillance } \\
\hline $\begin{array}{l}\text { Establish a Financial Stability Department with the mandate to develop policies } \\
\text { to manage systemic risk and foster financial stability (NBT). }\end{array}$ & High & Near term \\
\hline \multicolumn{3}{|l|}{ Crisis Management, Bank Resolution, and Financial Safety Nets } \\
\hline Resolve AIB in accord with global good practice (NBT and MOF). & High & Immediate \\
\hline $\begin{array}{l}\text { Bring the current bank resolution framework in line with global good practice; } \\
\text { introduce system of Prompt Corrective Actions requiring the NBT to take } \\
\text { sanctions against banks when defined criteria of bank distress are breached; } \\
\text { make NBT the resolution authority/liquidator for banks (NBT). }\end{array}$ & High & Immediate \\
\hline $\begin{array}{l}\text { Establish a Financial Stability Committee (FSC) as the lead coordination body } \\
\text { for crisis preparedness and management, and institutionalize the responsibilities } \\
\text { of the FSC members in the legal framework (NBT). }\end{array}$ & High & Near term \\
\hline $\begin{array}{l}\text { Strengthen the capacity of DIF to fulfill its mandate, the funding and payout } \\
\text { procedures, and reassess the coverage level (DIF). }\end{array}$ & Medium & Near term \\
\hline \multicolumn{3}{|l|}{ Insurance Oversight and Development } \\
\hline $\begin{array}{l}\text { Create an independent and adequately resourced insurance supervisor with a } \\
\text { mandate for regulation and market development, and abolish the state monopoly } \\
\text { in provision of insurance products (SISS). }\end{array}$ & High & Medium term \\
\hline \multicolumn{3}{|l|}{ Financial Inclusion, Bank Competition, and Consumer Protection } \\
\hline $\begin{array}{l}\text { Redesign the lending program of the Fund for Development of Entrepreneurship } \\
(\mathrm{MoF}, \mathrm{GoT}) .\end{array}$ & High & Near term \\
\hline $\begin{array}{l}\text { Operationalize NBT's mandate for financial consumer protection by creating a } \\
\text { division that gradually builds up the capacity for consumer protection across all } \\
\text { financial services (NBT). }\end{array}$ & Medium & Medium term \\
\hline \multicolumn{3}{|l|}{ Financial Market Infrastructure } \\
\hline $\begin{array}{l}\text { Address the risks for the payment system, including settlement risk from large- } \\
\text { value interbank payments and operational risk (NBT) }\end{array}$ & High & Near term \\
\hline $\begin{array}{l}\text { Improve the legal/regulatory framework for mortgage, pledge and bankruptcy, } \\
\text { and set up a new collateral registry for movables (MOJ). }\end{array}$ & Medium & Near term \\
\hline \multicolumn{3}{|l|}{ Overall Financial Development and Stability } \\
\hline $\begin{array}{l}\text { Develop a comprehensive strategy for achieving greater financial stability, } \\
\text { efficiency, and inclusion accounting for possible policy tradeoffs and synergies } \\
\text { in promoting the three financial sector outcomes (NBT, MoF, GoT). }\end{array}$ & High & Medium term \\
\hline
\end{tabular}




\section{MACROECONOMIC ENVIRONMENT AND FINANCIAL SECTOR}

\section{OVERVIEW}

\section{A. Macroeconomic Background and Outlook}

1. Tajikistan's economy is small and vulnerable to shocks. It relies heavily on imports (65 percent of GDP) and its exports (19 percent of GDP) are narrowly-based and largely commodity-driven (aluminum, cotton, and gold). Most of its fuel and a large share of food are imported. Tajikistan depends heavily on exports of labor and the resulting remittance income (equivalent to about 50 percent of GDP in 2013), earned mainly by migrant workers in Russia. The vulnerabilities are exacerbated by a poor business climate as the country stands the last among the seven Caucasus and Central Asia (CCA) countries in terms of the ease of doing business (Figure 1 in the Appendix).

2. GDP growth in 2014 was strong, but is likely to slow considerably in 2015 and over the medium term. Activity in 2014 was supported primarily by the rapid expansion of construction ( 25 percent), with the growth rate declining to 6.7 percent from 7.4 percent in 2013. Remittances fell by 8.4 percent in 2014 and are estimated to decline by 35 percent in 2015. This will have an adverse impact on the services sector and growth. While rapidly growing economic ties with China may help underpin the outlook, the fallout from the adverse external environment - most notably, in Russia - and the slow pace of structural reforms will likely weigh heavily on growth in 2015 and beyond.

3. Inflation rebounded from recent lows and is projected to pick up. The CPI grew between 3 percent and 7 percent during the last two years, owing to a relatively stable exchange rate and favorable international food and fuel prices. However, recent electricity tariff increases, ongoing rapid credit growth, and a pass-through from exchange rate depreciation (see below) are expected to push inflation into double digits in 2015.

4. Monetary policy has been largely accommodative. Base and broad money grew at 13.2 percent and 7 percent in y-o-y terms through December 2014, but private credit growth surged by 31.5 percent during the same period. Although direct NBT (liquidity) lending to banks has been limited, the placement of government deposits with commercial banks has supported the liquidity of several large banks (including those in violation of prudential norms) and fueled already high credit growth. The policy rate - the NBT's refinance rate-remained negative in real terms until recently. To help contain inflation and temper credit growth, further exchange rate depreciation should be accompanied by tight monetary conditions going forward. However, credibility of the NBT and its ability to perform its functions well might be affected by continued losses and negative capital.

5. The external position continues to deteriorate, putting pressure on the somoni (SM) and eroding already low external buffers (Figure 2 in the Appendix). The official exchange rate depreciated by about 10 percent during 2014, which is significantly less than that of most major trading partners (e.g., 18 percent in Kazakhstan, 17 percent in Kyrgyz Republic, and 107 percent in Russia). A relatively strong somoni (which kept import growth high) 
together with falling remittances and depressed exports (largely of cotton and aluminum) sharply eroded the current account balance. Absent compensating inflows on the capital account side, the authorities intervened heavily in the foreign exchange market, leaving international reserves at the level of nearly one month of imports by end-2014. Low reserves in an environment of high dollarization significantly constrain the effectiveness of systemic liquidity management by the NBT.

\section{The fiscal stance remains consistent with debt sustainability, but faces risks} stemming from weak banks, unreformed SOEs, and a potentially massive public investment program. Preliminary fiscal data for 2014 show a surplus (excluding the foreignfinanced public investment program). The budget is expected to be in balance or in small surplus over the medium term and the total public and publicly guaranteed debt is projected to remain below the government's benchmark of 35 percent of GDP. Fiscal risks, however, remain high. The construction of the massive Rogun Hydropower Project (HPP) may endanger debt and external sustainability. In addition, the fiscal position may be adversely affected by possible costs of bank recapitalization as well as external debt service-related budgetary outlays on behalf of two loss-making SOEs: TALCO, the aluminum company, and Barki Tajik, the electricity monopoly.

\section{B. Financial Sector Structure}

7. The financial sector is dominated by banks. The banking sector accounts for 84 percent of total financial sector assets (Table 2). Microfinance institutions (MFIs) account for most of the remainder. There is a small insurance sector and practically no capital markets activity or advisory services industry. Leasing sector is small, unregulated, while data on operations of leasing companies is not readily available. Recently, a license was issued for a new credit bureau to replace the existing one that is facing tax problems.

\begin{tabular}{|c|c|c|c|c|c|c|c|c|c|}
\hline \multicolumn{10}{|c|}{ Table 2. Tajikistan: Financial System Structure, 2012-2014 } \\
\hline & \multicolumn{3}{|c|}{ September 2012} & \multicolumn{3}{|c|}{ September 2013} & \multicolumn{3}{|c|}{ September 2014} \\
\hline & Number & $\begin{array}{r}\text { Assets } \\
\mathrm{mln} \text { SM }\end{array}$ & $\begin{array}{l}\text { Percent } \\
\text { of total }\end{array}$ & Number & $\begin{array}{r}\text { Assets } \\
\mathrm{mln} \text { SM }\end{array}$ & $\begin{array}{l}\text { Percent } \\
\text { of total }\end{array}$ & Number & $\begin{array}{r}\text { Assets } \\
\mathrm{mln} \text { SM }\end{array}$ & $\begin{array}{l}\text { Percent } \\
\text { of total }\end{array}$ \\
\hline Commercial Banks & 16 & 8,884 & 87.3 & 16 & 10,663 & 84.2 & 17 & 13,310 & 84.4 \\
\hline Fully state-owned banks & 1 & 1,245 & 12.2 & 1 & 1,586 & 12.5 & 1 & 1,812 & 11.5 \\
\hline banks with majority foreign participation & 7 & 910 & 8.9 & 7 & 1,043 & 8.2 & 7 & 1,345 & 8.5 \\
\hline Microfinance Instituitions (MFIs) & 124 & 1,146 & 11.3 & 118 & 1,803 & 14.2 & 121 & 2,265 & 14.4 \\
\hline Micro-credit Deposit Organizations (MDOs) & 34 & 492 & 4.8 & 37 & 1,499 & 11.8 & 41 & 1,912 & 12.1 \\
\hline Micro-loan Organizations (MLOs) & 44 & 547 & 5.4 & 42 & 155 & 1.2 & 42 & 192 & 1.2 \\
\hline Micro-loan Funds (MLFs) & 46 & 108 & 1.1 & 39 & 148 & 1.2 & 38 & 160 & 1.0 \\
\hline Non-Banking Credit Organizations & 1 & 1 & 0.0 & & & & & & \\
\hline Insurance Companies & 15 & 142 & 1.4 & 16 & 204 & 1.6 & 18 & 197 & 1.3 \\
\hline Leasing Companies $^{1 /}$ & 7 & & & 12 & & & 12 & & \\
\hline TOTAL & 174 & 10,174 & 100 & 162 & 12,670 & 100 & 167 & 15,772 & 100 \\
\hline (in percent of GDP) & & 28.1 & & & 31.3 & & & 34.6 & \\
\hline
\end{tabular}




\section{Commercial banks}

8. The banking sector remains small compared with CCA countries and is fairly concentrated. It reports assets of less than 30 percent and loans of 15 percent of GDP, and comprises 17 commercial banks, including one fully state-owned, one majority state-owned, and seven majority foreign-owned banks. The share of majority foreign-owned banks is 10.5 percent of total bank assets. The six largest banks account for 81 percent of total bank assets.

9. Official numbers mask major asset quality weaknesses in some banks. NPLs have grown rapidly, especially in large banks. For the six largest banks, the NPLs account for 28.3 percent of loans against the industry average of 25.1 percent as of December 2014. Banks are under-provisioned, with specific provisions accounting only for 42.7 percent of NPLs. resulting in an overstatement of banks' capital positions. With an interest margin to gross income of 32 percent, an expected increase in provisioning will erode margins. Banks rely mainly on retail funding, but the share of credit lines is growing.

10. While some progress had been made on AIB restructuring, further postponing the final decision is likely to result in a higher fiscal cost. The authorities believe that the recent appointment of a new Chairman will expedite the collection of NPLs and position the bank well for new lending. However, this may delay the needed resolution and restructuring of the bank. Therefore, the authorities should pursue the restructuring of the AIB without delay, consistent with best practices of bank resolution, as also outlined in the joint IMF-WB May 2014 TA report on AIB resolutions options, to reduce system-wide moral hazard and jumpstart lending by the bank. Given the systemic nature of AIB, the preferred options would be recapitalization with conditions or a bridge bank (Box 1).

11. The sector suffers from the legacy of directed lending. Although the extent of directed lending has declined markedly, the misallocation of credit is likely to have imposed important economic and fiscal costs. While these are difficult to measure precisely, due to data and analytical limitations, illustrative calculations can be constructed based on the literature on the effects of financial deepening on growth (e.g., Beck, Levine, Loayza, 2000). For example, assuming that nearly 50 percent of AIB's loan book consists of nonperforming loans due to directed lending, this could have reduced annual GDP growth by as much as $1 / 4$ percentage points. And while the fiscal costs are also hard to measure, restructuring AIB could require the injection of public funds in an amount equivalent to around $2 \frac{1}{2}$ percent of GDP (Box 1). 


\section{Box 1. Options for Resolving Agroinvestbank}

AIB is a troubled bank with negative regulatory capital, classified by the NBT as systemically important. The delay in its resolution negatively affects market discipline in the overall system, imposes costs on the real economy, feeds moral hazard of other troubled banks, and could have other adverse spillovers to the rest of the banking system.

There are three options:

(1) Recapitalization with conditions: This would involve writing down existing shareholders, restricting dividends, injection of government capital, and eventually re-privatizing the bank to reputable investors. This would not require legal changes, but would carry fiscal costs of $1 \frac{134-21 / 2}{2}$ percent of GDP. The risk of this approach is that - absent strong safeguards - the AIB's business model would remain unchanged, the legacy loan portfolio would weigh heavily on its financial performance going forward, exposing the public to the need for a further bail-out.

(2) Bridge bank resolution based on a revised legal framework for bank resolution: This would entail placing the bank under a temporary administration, until the legal framework is amended to allow for stronger resolution tools that would allow the transfer of insured deposits and "good" assets to a bridge bank, and the liquidation of "bad" assets and remaining liabilities by a "bad" bank. This approach would have a lesser fiscal cost, given the bailing in of creditors and large depositors, and would leave the new "good" bank with a healthier balance sheet and therefore more likely to be viable.

(3) Bank liquidation under the current framework: This would entail withdrawing the AIB's license, initiating a court-led liquidation, compensating insured depositors, and covering other creditors by the proceeds of liquidation. There would be no immediate fiscal costs, but the franchise value of AIB would be lost, and the potential for a generalized loss of depositor confidence would be greater.

\section{Insurance sector}

12. The insurance sector is small and underdeveloped. Eighteen companies currently operate in Tajikistan, one of which is foreign owned and two are state owned, with aggregate assets of SM 197.2 million (0.4 percent of GDP). The sector collected SM 138 million in 2013 and SM 84 million during Q1-Q3 of 2014 in insurance premia. It is supervised by the State Insurance Supervisory Service (SISS), which is a unit of the Ministry of Finance. Discussions are underway to move this function to the NBT. The legal framework allows for 15 types of mandatory and 32 types of voluntary insurance products. Life insurance is particularly underdeveloped and amounts to less than 2 percent of total gross insurance premiums.

\section{Microfinance institutions}

13. The microfinance sector has experienced sustained growth in recent years and the largest institutions compete directly with banks for SME lending. The sector is comprised of three tiers of institutions: 42 micro-credit depository organizations (MDOs), 42 micro-credit organizations (MCOs), and 36 micro-credit funds (MCFs), all serving over 400,000 borrowers. Microfinance institutions (MFIs) represent 14.7 percent of the financial system assets with a total active loan portfolio of TJS1.7 billion (US\$316 million) as of October 2014. The sector is 
also relatively concentrated, with the five largest MFIs accounting for around 70 percent of total assets. The large dominant players also compete with banks in the SME segment with similar interest rates and maturities. One microfinance organization acts exclusively as a wholesaler to smaller institutions.

\section{Leasing}

\section{The leasing sector is small and unregulated, with no market monitoring or} oversight, making it difficult to get even a general understanding of the sector dynamics. As of 2013, the market size was estimated at SM 62.4 million (US\$11.6 million) according to a study commissioned by the IFC. Banks and MFIs can provide leasing on their books, but the size of their financial leasing transactions is insignificant and stands at about SM 2.2 million (US\$400,000). About 90 percent of leasing transactions correspond to financial leasing, 10 percent relate to leaseback transactions, while operational leasing appears to be nonexistent.

\section{Capital markets}

15. The capital market is limited to an emerging government debt market, in addition to NBT's open market operations. The government securities market is comprised of 91-day treasury bills (T-bills) issued by the NBT's open Market Operations Department, which acts as an agent of the government. In 2014, the total volume of T-bills issued through five auctions was SM 154.8 million (around US\$29 million) with an average interest rate of 0.4 percent. The only two auction participants included state-owned Amonatbank and the Deposit Insurance Fund. The NBT's open market operations are more vibrant and include weekly auctions and instruments with maturities of 7, 14, 28, and 56 days respectively. Most recently, the authorities have established a closed joint stock company "Securities Market of Tajikistan" (100 percent owned by the NBT), with a mandate to develop a secondary market for government securities and to establish a new stock exchange. In addition, Tajiksodirotbank has registered a company under the name "Dushanbe Stock Exchange." However, there are no market activities as the company has not yet been issued a license to operate as a stock exchange.

\section{Progress with 2007 FSAP Recommendations}

16. Tajikistan made progress on 2007 FSAP recommendations. The authorities at least partially implemented many of the key recommendations of the 2007 FSAP. In the banking sector, the surveillance framework for monitoring the build-up of credit risk has been strengthened and a wide range of corrective measures introduced. Cotton debt resolution strategy was developed and largely implemented. Governance and autonomy of the NBT were enhanced, and some funds transferred to recapitalize the NBT. Bank regulatory and supervisory framework was strengthened. In the nonbank financial sector, program of government securities issuance was launched; the new laws on Deposit Insurance of Individual Savings (2011) and Credit Histories (2009) were adopted and were largely aligned with good international practice. Table 3 in the Appendix outlines the specific steps that have been taken and those remaining to be addressed. 


\section{FINANCIAL SECTOR STABILITY}

\section{A. Key Macro-Financial Risks and Vulnerabilities}

17. As the economy is entering a downturn, the financial sector faces a number of key risks. Current financial conditions are characterized by: (i) a high level of dollarization; (ii) high private credit growth; (iii) weaknesses in public sector borrowers (government agencies and state-owned enterprises); (iv) government-directed lending and poor corporate governance; (v) reliance on nonresident funding; (vi) substantial concentration risks, both in banking sector and in the loan books; and (vii) high spreads and interest rate margins. The remainder of this section discusses these risks in detail.

18. Dollarization in financial sector has been increasing and remains a challenge for FX risk and credit risk management of credit institutions. Prior to global financial crisis, it has been as high 82 percent and 76 percent, for bank loans and deposits, respectively. From early 2011, both indicators of dollarization have been on the rise, reflecting lack of confidence in somoni and risky business environment. The overwhelming majority of private enterprises that borrow in foreign exchange earn income in somoni and thus are not hedged against depreciation. Since Tajikistan is very vulnerable to frequent external shocks, historical episodes of substantial depreciation imposed significant costs on Tajik banking system. High dollarization also complicates monetary policy management and crisis resolution.

19. Rapid credit growth in a worsening macroeconomic environment is likely to make the system more vulnerable. Credit boom in Tajikistan in 2014, with private credit expanding by 31.5 percent, was accompanied by compressing real economy, exchange rate pressures, and slowing monetary aggregates. The placement of government deposits with commercial banks had supported the liquidity in the system and fueled already high credit growth. Weak underwriting standards, legacy of directed lending, and regulatory forbearance have likely encouraged undue risk taking in the past. In addition, credit quality is impacted by weaknesses in formal credit assessment methodologies and insufficient credit information. Moreover, credit growth has exceeded the deposit growth, pushing loan-to-deposit (LTD) ratio above 100 percent. The FX loans have been expanding at a faster rate, exposing the banks to indirect credit risk as a result of potential depreciation (Figure 3 in the Appendix). Much of the fresh credit went into an unhedged and riskier segment: construction and consumer credit. As an early sign of mounting vulnerabilities the NPLs in banks nearly doubled to 22 percent at end-September 2014 compared to 11.7 percent a year ago.

20. Weaknesses among public sector borrowers represent another key macro-financial risk. Following a deteriorating macroeconomic environment and without explicit future budget support, state-owned companies (particularly large ones, such as, Barki Tajik, TALCO, and Tajik Air) will likely have difficulties servicing their loans going forward and will likely undermine financial sector performance by raising NPLs and eroding banks' capital buffers. At end-2014, the share of government and SOEs in total bank credit was about 11 percent. 74 percent of these loans were overdue for $30+$ days, the worst ratio among all economic sectors. 
21. Government-directed lending and poor governance at banks have increased credit and concentration risks. Exposure of one large bank receiving this liquidity to the construction sector has increased five-fold in 2014. Another bank, which accounts for 50 percent of government on-lending, has an NPL ratio that is more than triple the industry average. Insider and connected lending is prevalent and interference in lending decisions is still not uncommon. This practice is often motivated by supporting flagship public enterprises facing difficulties or by food and fuel security considerations. If not terminated, directed lending will continue to take a toll on the financial sector and will inhibit expansion of healthy credit to best value use (see the Box on AIB, the main vehicle for directed lending recently).

22. An increasing share of foreign currency loans without adequate hedging in both banking and microfinance sectors may negatively affect the quality of loan portfolios. About 26 percent of banks' and MDOs' combined liabilities in 2014 were funded by the nonresident loans, deposits, and credit lines from foreign banks, nonbanks, and international financial institutions MDOs are particularly affected, as they obtain most of their funding from external sources because of low deposit mobilization, with banks capturing 97 percent of all deposits. About 80 percent and 47 percent of MFI's total funding and loans, respectively, are in foreign currency. The risks of deteriorating portfolio quality are especially high in light of recent currency depreciation and further pressures transmitted from Russia which are likely to negatively affect the unhedged local borrowers.

23. The high concentration of loans exacerbates vulnerabilities of banks. The risk is concentrated in commercial loans (46 percent of the total NPLs), loans to government entities (30 percent of total NPLs), and loans to SMEs (14 percent of total NPLs) (Figure 4 in the Appendix). However, as a percent of the total loans provided to each particular sector, the highest risk is concentrated in public sector (74 percent of total government and SOE credit is past due), commercial sector (31 percent), and agriculture (21 percent). Loans are also concentrated across issuing banks. The six largest banks account for 85 percent of total bank lending, while the top three account for 62 percent of total loans.

\section{Interest rates remain high, reflecting poor business environment and elevated} credit risk (Figure 5 in the Appendix). High interest margins/spreads point to inefficiencies in intermediation and may impede economic growth by discouraging productive investments. Lending-deposit rate spreads have been increasing since mid-2011 and remain elevated: 10 percent in somoni and 13.7 percent in FX on average during 2014. For deposits, there is a consistent difference between somoni and FX rates (of about 250 basis points), likely reflecting the depositors' desire to be compensated for high/volatile inflation and lack of trust in somoni.

\section{B. Banking Sector Vulnerabilities}

\section{Overview and scenarios}

25. Quantitative tests were conducted to assess banks' resilience to credit and liquidity shocks. These included macroeconomic stress tests, single factor sensitivity analysis, and top- 
down solvency stress tests on nine banks using supervisory data through end-September 2014. The results should be interpreted with care due to data limitations and quality considerations. The banking system's resilience was assessed against three scenarios: baseline, adverse moderate, and adverse severe.

\section{Solvency risk}

26. Macro credit risk stress tests suggest that the banking sector is vulnerable even under the baseline scenario. When the existing provisioning rates were used, the projected NPL ratio for the sector increased slightly (by 1.4 percentage points) to 21.5 percent in 2015 with the system-wide CAR remaining above the regulatory minimum at 18.1 percent. When full provisioning was assumed, the system-wide CAR falls to 16.8 percent with three institutions (including two large banks) representing more than a third of the system assets falling below the regulatory threshold.

27. Significant strain appears in the system under the severe stress scenario. In the moderate adverse scenarios, loan quality deteriorates with NPL ratio for nine banks reaching 23.2 percent in 2015. The deterioration intensifies under the severe adverse scenario: the system-wide NPL increases to 30 percent in 2015. While this still leaves the CAR above the regulatory minimum (due largely to significant underprovisioning), the scenario changes dramatically for the largest banks when full provisioning assumption is imposed, forcing the CAR to fall below 15 percent (accounting for nearly two-thirds of total banking assets).

28. Credit risk is the most critical risk for Tajikistan's banking system. The results of sensitivity analysis are consistent with those of the macro credit risk stress test. Under the current provisioning rate, a 150 percent increase in aggregate NPLs raises the number of large banks failing to comply with the regulatory requirement (three banks accounting for 42 percent of total banking assets and 0.6 percent of potential recapitalization amount in percent of GDP ). Against regulatory provisioning requirements, increases in NPLs have a far more significant impact on CAR, which turns negative. The system-wide CAR falls by 14 percentage points to 3 percent while the potential recapitalization amount in percent of GDP increases to 2.6 percent.

29. The largest banks are more vulnerable to concentration risk. The test shows that in the event of a default by the largest borrower and full provisioning rates, the CAR of the largest banks will fall from 11.2 percent to 9 percent. For the smaller banks, the CAR will decline by 3 percentage points (to 36 percent). If the top five borrowers default, the largest banks' CAR will drop by 7 percentage points to 4 percent, while the smaller banks' CAR will reach 34 percent.

\section{Interest rate risk appears to be contained, but banks face considerable exchange}

rate risk. Interest rate risk is not significant for banks due to small maturity mismatches. Even with an interest rate shift of up to 800 basis points, the impact on CAR is marginal falling by only 2 percentage points, remaining above the regulatory threshold. Banks are less resilient to a severe currency shock: a (direct impact of) depreciation of the somoni by 50 percent lowers the 
banking system's CAR to 19 percent. Four banks, including two large banks, fail to meet the capital regulatory requirement. After imposing full provisioning the number of banks in breach of the regulatory minimum increases to 5 and the system-wide CAR falls to 13 percent.

31. The banking sector was also stress tested for the indirect exchange rate risk. The tests looked at an increase in FX NPLs to "unhedged borrowers" (which account for 85 percent of total FX loans). Each indirect credit risk single factor shock is then combined with the direct effects of exchange rate depreciation. Under a (moderate) 25 percent depreciation of the somoni, a 38 percent increase in FX NPLs, and regulatory provisioning, the system-wide CAR falls to 13 percent, with the CAR for large banks falling below the regulatory minimum of 15 percent. Similar results were observed when loans of unhedged borrowers were combined with direct FX effects. The losses are further accentuated under the adverse severe scenario.

\section{The results of the multi-factor stress test suggest that the banking sector is} vulnerable to adverse scenarios. Under the adverse moderate scenario, the banking sector's capital ratio falls to 15.7 percent and one bank becomes insolvent. In the adverse severe scenario, the CAR falls to 14.6 percent, three banks become insolvent. The shock has a significant impact on the capital ratio of large banks, which declines to 7.5 percent.

\section{Liquidity risk}

\section{Banks appear vulnerable to a run on foreign currency deposits and, to a lesser} extent, to a run on domestic currency deposits. The liquidity stress test focused exclusively on funding liquidity risk since assets could not be evaluated, market liquidity risk (i.e., the drop in asset prices due to selling pressures) could not be quantified. Under a run on FX deposits, one bank exhausted its liquidity on the second day. By the fifth day, six banks became illiquid, amounting to 42 percent of banking assets. As for a run on domestic currency deposits, banks are less vulnerable as only one bank became illiquid on the third day, representing 2 percent of banking sector assets.

34. Another liquidity test simulated the impact of withdrawal of the largest one, three, and five depositors. The test measured against a hurdle rate of 30 percent of liquid asset to total asset ratio, suggests that the banking sector is highly concentrated as it does not have sufficient liquidity against large and sudden outflow of deposits. 


\section{REGULATORY AND SUPERVISORY FRAMEWORK}

\section{A. Microprudential Oversight}

\section{The authorities made progress in reforming the legal and regulatory framework}

for the financial sector following recommendations of the 2007 FSAP (Table 5); however, the following structural weaknesses remain and impose significant handicaps to safe and sound banking and effective banking supervision:

- The NBT does not have a mandate for fostering stability of the financial system as a whole. It is only responsible for banking sector stability.

- The judiciary is not used by the banks to support contract enforcement, due to excessive uncertainty about duration and outcome of lawsuits.

- Enforcement of prudential standards is still weak, in particular at the large and systemically important banks, and there is no capacity in the banking supervision function to assess macro-prudential risks which can be valuable early warning signals for financial distress.

- There is no central registry where companies' financial statements are deposited and can be examined.

- Accounting standards are still a hybrid of IFRS and pre-independence/Soviet accounting. The auditing profession in Tajikistan is still relatively young. Practical experience requirements for bank auditors have been relaxed.

- The effectiveness of the new law on Liquidation of Banks has not been tested.

- Conditions for the effective exercise of market discipline are not favorable as there is virtually no interbank market or a securities market to provide a pricing mechanism to enforce prudent risk taking by banks.

\section{While the supervisory framework is broadly in place, problems remain that} require immediate action. Insufficient numbers of staff and outdated technical resources are bottlenecks for the effectiveness of supervision. Proper inspection of loan portfolios - one of the most critical functions of banking supervision - is time-consuming. There is a considerable need for training, keeping abreast of supervisory developments and building macroprudential skills. Lack of time can lead to superficial compliance-oriented inspections, which risk undermining NBT authority and staff morale. Moreover, a broader skill mix is needed within the department, and specialists in IT, economic and mathematical modeling, as well as risk assessment should be recruited. The BSD is also responsible for developing policy development, drafting of regulations, and methodology, which should be done separately.

37. The NBT needs to work with banks to reduce the NPLs overhang. Specifically, it should order banks to adequately classify the loans, use all legal means to rigorously and promptly enforce loan contracts, limit loan restructuring or ever-greening, and write off 
noncollectible debt. Any tax-disincentives for provisions and write-offs should be eliminated. The NBT should review progress with the banks on a quarterly basis.

38. In general, enforcement remains problematic, in particular with regard to the large systemic banks. Governance issues still substantially hinder effective supervision. In addition, staffing shortages hinder full investigations into non-compliant or unsafe and unsound practices, limit the follow-through in appeals cases and media inquiries into high profile enforcement cases. In the post-inspection letters from NBT to the banks, consideration should be given to a more rapid escalation to binding instructions from the NBT, and prompt follow up on banks' corrective actions. It is important to build a reputation for NBT of a strict enforcer of regulations and of safe and sound banking. Furthermore, a level playing field needs to be maintained to guarantee adequate supervision for both large and small banks.

\section{B. Macroprudential Oversight}

39. Macroprudential surveillance at the NBT is still at a rudimentary stage. The "Law on the National Bank of Tajikistan (LNBT)" allows the NBT to carry the responsibility of establishing prudential standards for lending institutions, but the mandate for financial stability and macroprudential policy are not explicitly specified in the legislation. The NBT has adopted a few macroprudential tools to limit various systemic risks, but overall both the tools and their use remain limited.

40. The existing institutional framework at the NBT is insufficient to deal with growing credit risks in the banking system. The function of macroprudential surveillance is constrained and dispersed in various departments and lacks resources. There is no integrated department/unit devoted to the macroprudential policy oversight. In spite of growing credit risks, the existing macroprudential toolkit has limited instruments to timely and effectively contain and mitigate credit-related systemic risks.

\section{There is a need for the NBT to establish a comprehensive macroprudential} framework and institutionalize it in a financial stability department. First, the mandate for financial stability and macroprudential responsibilities should be explicitly codified in the law. Second, the institutional function should be strengthened. Second, a Financial Stability Department (FSD) should be established to integrate various macroprudential functions within the NBT. FSD should have a power to make propositions to the Board on how to apply macroprudential instruments, particularly those under the purview of BSD and CRG. The head of FSD should be appointed by the NBT Board; and its staff should be selected from experienced and knowledgeable staff from the BSD, the MPD, and the CRG; and external expertise could be recruited. The FSD's main responsibility should be to analyze the development of the domestic and global financial systems; identify vulnerabilities and emerging risks; review and design the macroprudential framework, methodologies, and instruments; conduct stress testing; analyze the efficiency of existing macroprudential measures; and compile an annual financial stability report. 
42. The NBT can also enhance the macroprudential toolkit to better manage financial cycles. The NBT should consider introducing additional macroprudential measures, especially credit-related tools that are effective in containing systemic credit risks stemming from rapid credit growth and excessive leverage. These could include: (i) caps on the LTD ratio; (ii) caps on the LTV ratio and debt-to-income (DTI) ratio; (iii) limits on specific sector exposures (e.g., real estate); (iv) caps on foreign currency lending; and (v) maximum or limits on leverage ratio. The FSD should consider Tajikistan's specifics and tailor the additional instrument to the banking sector in combination with existing microprudential tools.

\section{Anti-Money Laundering and Combating the Financing of Terrorism}

\section{The Anti-Money Laundering and Combating the Financing of Terrorism} (AML/CFT) assessment of Tajikistan was carried out by the World Bank in 2007. In addition, the mutual evaluation report was adopted by the Eurasian Group (EAG) on combating money laundering and financing of terrorism. ${ }^{2}$ Tajikistan was rated partially compliant or noncompliant on 44 out of the 40+9 Financial Action Task Force (FATF) Recommendations, noting the absence of an AML/CFT regime and of a strategy to prevent, detect, disrupt, dismantle ML/TF, or to investigate, prosecute and confiscate the proceeds of these crimes. Due to the identified strategic deficiencies, the EAG placed Tajikistan under the enhanced follow-up procedure and in June 2011 the International Co-operation Review Group (ICRG) included Tajikistan under its targeted review.

\section{In recent years, Tajikistan managed to establish a comprehensive legal and} regulatory AML/CFT system and adopted several measures necessary to effectively prevent and repress the ML/TF. These included the adoption of the AML/CFT Law, amending the Criminal Code, the Law on Banking and other sectoral laws, bylaws, and guidance. In February 2010, the Financial Monitoring Department of the NBT (the financial intelligence unit) was established. In July 2012, the Tajik FIU became a member of the Egmont Group, which means that it met all the Egmont Group and FATF legal and operational requirements related to its status, core functions, data protection, and ability to exchange information with foreign competent authorities. In October 2014, the FATF acknowledged Tajikistan's significant progress in improving its AML/CFT regime and removed Tajikistan from its global AML/CFT compliance process. In November 2014, the EAG also removed Tajikistan from its enhanced follow-up procedure. Tajikistan will be assessed under the revised 2012 FATF 40 Recommendations in 2017.

\footnotetext{
${ }^{2}$ Tajikistan is a member of EAG.
} 


\section{CRISIS PREVENTION AND MANAGEMENT FRAMEWORK}

45. Urgent improvements of the framework for crisis prevention and management, including bank resolution, are needed. The continuing problems in AIB have a negative effect on the real economy (Box 1). As the sector remains strained, the authorities need to be prepared for rapid and effective response to a bank in distress or a system wide crisis. For this reason, new forms of cooperation are needed as well as a more effective use of already existing powers and tools. Importantly, Tajikistan needs to revise its bank resolution framework and bring it to the level of international best practice.

\section{The proposed Financial Stability Committee (FSC) should take on the role of an} interagency coordination body for crisis preparedness and management as well as contingency planning. Its existence would ensure that each member of the financial safety net understands its role and responsibilities and the actions of the different players are coordinated at all stages. The FSC functions and responsibilities of all FSC members should be institutionalized in a law to ensure adequate accountability. The new body would develop contingency planning for crisis management to guide all authorities. The planning would identify the responsibilities and actions of each authority in the implementation of different forms of resolution options foreseen under the new bank resolution framework (see below). This framework would also involve the development of a joint communication strategy with stakeholders and the public/media for various measures and resolution approaches.

47. Once the resolution framework is revised and the authorities have assumed their new roles and powers, a crisis-simulation exercise should be conducted to create awareness about the changes within the financial safety net and identify outstanding issues. It is recommended that this exercise be periodically repeated using different scenarios to test the adequacy of the legal framework and the contingency plans.

\section{A. Emergency Liquidity Assistance}

\section{The NBT can provide Emergency Liquidity Assistance (ELA) to banks in both} somoni and foreign currency. In practice, foreign currency loans are limited to Russian rubles. In addition, the existing liquidity window does not distinguish between regular liquidity provision and ELA. According to the law, only solvent but temporarily illiquid banks can apply for the loans from the NBT. The approval of the loan is decided by NBT's Credit Committee, which consists of members of the Supervision, Legal, and Monetary Policy Departments, and the Risk Division. The decision-making process entails an assessment of the bank's solvency, the overall health of the bank, and the valuation of the collateral provided. ELA is available for a maximum of three months (can be extended to six, with a remedial action plan), and is priced above inter-bank interest rate benchmarks. Five banks have applied for liquidity assistance in 2014, with SM 400 million of ELA approved in total. Going forward, the newly established bank resolution authority (see below) should be part of the Credit Committee to differentiate the risk assessment from recovery and resolution. 
49. Lack of sufficient eligible collateral in the form of government or NBT securities is a problem. The NBT requires collateral for all liquidity provisions. In practice, only correspondent accounts and real estate function as collateral, because the securities market is very small. Since the registration of real estate is time consuming, the NBT has introduced a mechanism by which borrowers can register collateral in advance. It can open a credit line of up to one year, with the condition of the collateral (e.g., real estate, etc.) defined. Haircuts from 30 percent to 50 percent are typically set by the NBT to reflect the quality of the underlying collateral in accordance with the assessment of the State Investment Committee. With the credit line in place, ELA can be approved within one day. Due to mounting liquidity pressures and unavailable collateral, the NBT urges more banks to open such credit lines.

50. In light of the pressing shortages of liquidity in the banking sector, the operational frameworks should be further improved. The NBT should only provide liquidity on a collateralized basis, as it has recently started to do. It should effectively block correspondent accounts when these are used as collateral. The Risk Division should get involved to assess the credit risk of individual transactions and determine individual haircuts. In practice, there is no clear line between liquidity assistance and ELA and some banks use the ELA facility to manage their periodic liquidity needs. The NBT, therefore, needs to critically reassess the ELA provisions and its terms and conditions going forward. In turn, the GoT should undertake steps to develop the securities market, which would have a positive effect on overall systemic liquidity management in the banking sector.

\section{B. Regime of Prompt Corrective Actions}

51. The NBT is responsible for imposing remedial measures and enforcing them, with specific measures to be guided by procedures of application. Corrective measures may include for example: ordering recapitalization of the bank, reclassification of the loan portfolio, additional provisions to cover possible loan losses, adjustments in capital and in calculation of the capital adequacy ratio, and prohibiting dividend payment or opening new branches. NBT has gained experience in applying those rules, as it has, for example, prohibited banks from distributing dividends and asked banks for action plans to improve their individual situation.

\section{The legal framework provides NBT with discretionary powers to enforce} corrective actions, but does not trigger NBT's mandatory action at a particular rating or capital adequacy level. Taking a certain action is optional (instead of required) for the NBT. The framework vaguely defines the criteria for unsafe and unsound banking practices and the applied measures are lacking some important elements (e.g., the suspension of deposit withdrawals of big depositors or shareholders, or senior management being subject to a fine apart from the bank itself).

53. The current PCA regime does not work satisfactorily as a result; the law should be improved and more specific internal guidance developed for supervisory intervention. ${ }^{3}$

\footnotetext{
${ }^{3}$ A CAMEL based early intervention regulation is still only in draft form.
} 
The lack of specific guidance and mandatory actions may lead to inconsistencies in application or even inaction at the sign of banking distress. Indeed, such inaction is apparent in some cases. Overall, there is a need to ensure that in future the culture and discipline of the financial policy stakeholders (e.g., supervision, enforcement, and resolution authorities) is conducive to prompt corrective actions and prohibits regulatory forbearance, which is a serious issue in Tajikistan.

\section{Bank Resolution Framework}

\section{There are significant deficiencies in Tajikistan's bank resolution framework.}

Currently, the laws only stipulate two ways to resolve a bank. The articles on provisional administration in the NBT law have weaknesses. The law is missing clear triggers for early intervention, which might lead to a late appointment of the provisional administrator. Further, provisional administration is disclosed to the public so it might lead to a loss of confidence in the institution and a further deterioration in the quality of assets. The resolution of goneconcern institutions as foreseen in the current Law on the Liquidation of Lending Institutions seems to be ineffective. Because of court involvement, substantial delays could occur before the opening of the liquidation process. Once the special administrator (liquidator) is appointed, the NBT has no real oversight over his/her work. The inadequate framework for bank resolution limits the options for the most pressing case, the resolution of troubled AIB (Box 1).

\section{Immediate action is needed to adopt a comprehensive and robust framework for bank resolution based on international best practice, including the FSB's Key Attributes for Effective Resolution Regimes. The framework should:}

- Set out the objectives of resolution and the principles on which resolution powers shall be used;

- Specify the triggers/grounds for the use of each resolution power;

- Ensure that shareholders and creditors (other than insured depositors and secured creditors) bear losses before other means of public funding are used; and

- Foresee that all resolution powers are subject to an ex post independent assessment so that no shareholder or creditor is left worse off (NCWO) than they would have been under a conventional liquidation.

\section{Under the new framework, NBT would be the resolution authority and the}

liquidator for failed banks. It is important that the new resolution framework sets out appropriate governance and accountability arrangements for the NBT in its new capacity as the resolution authority to mitigate the potential conflicts that can arise between supervision and resolution, such as regulatory forbearance causing delays in the activation of resolution. Going forward, it would be appropriate to require that early intervention powers are kept with the current supervisory division, while the resolution functions should be administered in a new division of the NBT that is separate from the supervision division. In addition, it is proposed 
that the resolution authority can wind-down the operations of an institution that are not critical to the financial system or the economy and that the NBT becomes automatically the liquidator. ${ }^{4}$

\section{The provisions of the Law on Liquidation of Lending Institutions on the hierarchy} of creditor claims in bank liquidations should be changed in accordance with best practice. Insured deposits currently do not enjoy a preferred creditor status (depositor preference). Therefore, the claims (and the deposit insurer subrogated to them after reimbursement) are likely to remain unrecovered due to the unfavorable treatment in the law. These claims should rank before uninsured deposits as well as claims of the Government and NBT but below the funds spent on the bankruptcy proceedings and special administration as well as wages of the failed bank's employees.

\section{Deposit Insurance}

58. The Deposit Insurance Fund (DIF) is a simple paybox established in 2003. The DIF's role is limited to collecting the quarterly premiums of member institutions, investing the funds in safe securities and when notified, reimbursing insured depositors up to the amount of SM 7,000 (US\$1,250). While this coverage level seems to be relatively small, it currently fully covers 72.9 percent of all depositors. Currently 54 deposit-taking financial institutions are members of DIF (14 banks and 40 micro-credit deposit organizations).$^{5}$

\section{The fund has experienced significant improvements since the adoption of the} deposit insurance law in 2011. The calendar contributions are set at 0.5 percent quarterly, which is among the highest rates globally. DIF has accumulated a sizable fund of over SM 171 million (US\$30 million) fully funded by the industry and reaching a ratio of 4.1 percent of total deposits at the end of 2014 (the statutory target fund ratio is set at 7 percent). With that amount, DIF could payout insured depositors of even the biggest banks in a single failure case. Since its founding in 2003, DIF has not have to payout depositors and is therefore lacking practical experience in handling reimbursements.

60. However, the effectiveness and the capacity of DIF could be strengthened. In view of the increased income level of the population and the unrecognized coverage level by the public, as well as the sizable but weak SME sector, a gradual increase of the coverage level, as well as broadening of its scope to cover SMEs should be adopted after a thorough assessment. An immediate increase of the coverage level up to SM 20,000 seems reasonable. DIF's target funding level and funding model should be revised to prevent an overburdening of the banking sector but considering the broadened scope and raised coverage level. Because DIF is making loss on the investment of its fund in real terms, its investment policy should also be revised. DIF is lacking pre-arranged contracts for its liquidity arrangement with NBT or the MoF, which might negatively affect its functioning when liquidity is thin and needed quickly. Furthermore,

\footnotetext{
${ }^{4}$ The NBT should be able to outsource the liquidation tasks to external experts (natural or legal persons).

${ }^{5}$ The fully state-owned Amonatbank is not part of the scheme because its deposits are guaranteed by the State.
} 
all deposit taking institutions, including state-owned banks, should participate in DIF to create a level playing field in the sector and to avoid adverse selection by depositors.

\section{DIF's current operational framework for the payout procedure lacks several} prerequisites and is hindered by ambiguities in the deposit insurance law. The trigger of its action is in practice subject to a dual action: revocation of the credit institution's license and formal decision of the court on declaring insolvency sent to the fund by NBT. While the credit institution is closed, the latter decision might take the court several weeks or even months as it was exacerbated in a recent case. Further, the DIF's staff has no hands-on experience in depositor payout as yet. The scheme is lacking an IT system that is vital to quick processing. There is no detailed operational payout-manual with a crisis-communication plan. Furthermore, IDIF should be allowed to use its funds to support the purchase and assumption of insured deposits by another bank or a transfer to a bridge bank under the "least cost rule."

\section{FINANCIAL SECTOR DEVELOPMENT}

\section{A. Credit Reporting Systems}

\section{There are two credit bureaus operating in Tajikistan licensed by the NBT while} there is no credit registry. The Credit Information Bureau Tajikistan (CIBT) was established in 2010 by an international service provider with a strong support of the banking and microfinance associations and started operations in 2013. It collects information from 17 banks and 56 micro finance institutions. CIBT holds information on about 602,000 individuals and 25,000 firms representing 887,000 credit transactions. In 2014, Bureau of Credit History Somonoyi, supported by the Association of Microfinance Organizations Tajikistan (AMFOT) and owned by local private companies and individuals, obtained a license from the NBT. In late 2014, it started conducting credit reporting activities with information from 5 banks and 80 small microfinance institutions. This bureau currently holds information on 120,000 individuals and 8,500 firms representing 332,000 credit transactions.

\section{The legal and regulatory framework covering credit reporting aspects include: (i)}

the Law on Credit History 2010 covering data protection aspects, oversight mandate, entry and exit criteria for service providers and general aspects on the collection of data; (ii) the Banking Law, as regards to bank secrecy provisions; (iii) the Law on the NBT specifying the role and mandate of the NBT in the credit information system; (iv) the Law on Microfinance as regards to sharing information from microfinance organizations (MFOs) and; (vi) the Law on Competition and Restriction of Monopolistic Activity in Commodity Markets. Regulations issued by the NBT further develops certain aspects of the above-mentioned laws including: (i) Instruction 177 on the order of establishment and formation of fund to cover potential loan losses; (ii) Instruction 181 on requirements for risk management and internal control system in lending institutions, and (iii) Instruction 186 on the order of loan provision and interest calculation by lending institutions. The "law on licensing individual activities" also impacts CRS activities. The NBT is currently finalizing the regulations for credit bureau licensing and 
guidelines on credit bureau supervision. The legal framework is completed by bilateral contractual arrangements between the service providers and the data providers or users.

64. Although the industry is still in early stages of development, both bureaus serve the credit market with positive and negative information. CIBT offers three types of credit reports at prices ranging from SM 6 to SM 35: (i) basic; (ii) expanded; and (iii) advanced, which includes a generic credit score. Although CIBT offers comprehensive data in their reports, the system does not have yet sufficient data to show a history of payments and classification of loans is not displayed in the report. Moreover, the reports do not include the creditor's name, previous enquiries, history of repayment on existing loans, or loan classification. KIBT plans to offer other types of services such as portfolio monitoring and parallel loans analysis. The Somonoyi offers a basic credit report including a snapshot of the situation of the borrower at the time of the enquiry. In addition, this report includes a separate section with information on the guarantor. It plans to offer credit scoring and data on collateral.

\section{The scope of data sources is limited to banks and micro finance organizations.}

There are additional data sources such as telecommunication, utility, and insurance companies holding relevant data to evaluate the creditworthiness of individuals. However, such data is not being collected by any of the two credit bureaus. The unified State Register for Legal Entities "Single Window" holds data on registration of companies and entrepreneurs, but there is no agreement to share this information with any of the two credit bureaus. Finally, INN (TAN and TIN) numbers recorded in the credit bureaus are not validated with the Tax Authority.

66. The NBT made remarkable efforts to establish a credit bureau in the country; however there is no strategy for the development and oversight of the credit reporting system as a whole. Creditors recognize the benefits of the credit bureau and welcome the existence of competition in the credit information market which helped lower prices for credit bureau services. Although sufficient data exist, creditors do not effectively use the information provided. Positive effects of credit reporting on the credit market (e.g. decreasing NPLs and operational costs, increasing access based on good credit history) remain to be seen and require adequate monitoring. Most creditors use credit reports for pre-screening, but the existence of good credit history has no impact on the interest rate setting for credit and loan products, and only minimal impact on the terms and conditions of the loan. In addition, several challenges remain such as: (i) reporting of the total portfolio of loans which impacts data quality; (ii) potential fragmentation of data between two bureaus; (iii) sufficient relevant data for the evaluation of SMEs, including such related to collateral; and (iv) supply of relevant information to support on-site and off-site supervision of banks as regards to large risk exposures. Finally, it is not clear how the information related to loans in foreign currency is collected and presented in the reports. All these aspects, together with a perceived lack of trust among competitors, call for a policy document stating short-term goals and long-term goals for credit reporting.

67. The existing legal framework presents challenges for the credit bureau operations. The existing law fails to address two conflicting objectives such as the need for collection of 
credit information by the credit bureau and the protection of confidentiality of information embedded in the legal and customary system for banking activities in Tajikistan. This issue was addressed by the introduction of a mandatory provision for data submission in the Law "On Credit Histories" and in regulations combined with the need to collect consumer's consent for data collection and also for data access. The law also presents some flaws regarding the protection of confidentiality by not limiting the use of credit information obtained from the credit bureau. In addition, it is not clear whether the reciprocity principle that allows users to access data only if they provide data is embraced by the system.

\section{The NBT bank and nonbank supervision requires reliable credit information} provided on a systematic basis from the entities subject to their supervision. Supervisors rely on synoptic reports issued periodically by the credit bureau and plan to have unrestricted access to credit bureaus in the near future. The NBT is also collecting certain pieces of information from the different banks and nonbank financial institutions (MDOs, MFOs, and MCOs) although this information is not stored in and organized manner in any database.

\section{The consumer protection framework for credit reporting has not been developed}

yet. There is no standard or agreed procedure to handle consumer complaints in the market. While each credit bureau deals differently with consumer complaints, users handle the complaints on a case- by-case basis. The role of the NBT in dispute resolution is not clear and no institutional framework is in place to support this function. Although the law allows for consumers to access their report once a year for free, reports are only provided at the premises of the credit bureau and do not include the name of the creditor, previous enquiries, and the reason for accessing the reports.

70. Authorities could prepare a Vision document for Credit Reporting with goals and objectives for the CRS from both the development and oversight perspectives. This document should include the following elements: (i) the scope of Credit Reporting Systems in Tajikistan including existing systems and planned systems; (ii) the role of the NBT in the oversight of the CRS, the main goals for the oversight, and the key instruments for inducing changes when necessary; and (iii) the role of the NBT as the user of credit information for purposes of prudential supervision and credit market monitoring. In preparing the Vision document, adopting the General Principles for Credit Reporting could serve as a guide for the adequate definition of goals aiming at the safety, effectiveness, and reliability of the CRSs.

\section{The prudential supervisory framework could benefit from the establishment of a} Credit Registry at the NBT. Acknowledging the current status of development of the credit market and the credit information market, the NBT should establish a Credit Registry that would enable a better supervision of the credit risk of the supervised entities and the financial system as a whole. Initially, the system could start by collecting information on large credit risk exposures from banks and large microfinance institutions. These large exposures could concern both legal and natural persons. Such information could be complemented by credit bureau data. This registry can serve to overcome the potential information gaps in the credit bureau for those 
consumers that do not provide consent. In addition, this registry is a suitable instrument to validate data quality in the credit bureau by comparing files from the different databases. Finally, information on interest rates could also be included in the registry which is very unlikely to be collected by a credit bureau.

\section{Credit bureaus should consider adopting common policies and principles} regarding consumer rights. The NBT as the overseer of the CRS could lead this effort and provide guidelines for the adoption of this policies and procedures, and coordinate this effort under the overall framework for consumer protection for financial services. For example, NBT could start providing guidance on the elaboration of a standard consent clause that would allow the collection of credit information from a broader number of consumers.

\section{B. Insolvency and Credit Rights}

73. The legal framework governing creditor/debtor relationships is quite modern and comprehensive. Several laws and institutions, however, should be improved to make creditor/debtor regimes more effective. Corporate lending is usually secured with real estate, a favored form of collateral and mortgage ('hypothec'), as the security mechanism preferred by banks: about 90 percent of the corporate loan portfolios is secured with mortgages. In 2014, the Collateral Registry under the Ministry of Justice ('State Registration of Mortgage Obligations') registered 10,798 mortgage agreements. Banks also take gold, money deposits and jewelry as collateral because the lender keeps possession of these assets until the loan is repaid and, in case of non-performance, the enforcement of possessory pledges is rather simple and effective. Non-possessory security rights over movable assets ('pledges') are not extensively used: in 2014, only 62 pledge agreements have been registered. Banks do not consider such pledges as secure. Flaws in the legislation governing pledges and a dysfunctional registration system for encumbrances over movable assets prevent an extensive use of movable assets as collateral, restricting access to credit -in particular by small and medium size businesses.

\section{Creating security rights over immovable assets is not problematic in general.}

Buildings and other immovable assets used in business activity can be mortgaged, as well as dwellings, flats, dachas, garages and other constructions considered as immovable property by the laws of Tajikistan. The Tajik state, however, has exclusive ownership rights over the land, and assigns land use rights to legal entities and individuals ('land users'). Primary land users are legal entities and individuals who have land plots either in tenure of unlimited duration or lifelong inheritable tenure. Secondary land users are legal entities and individuals who use plots of land on land-lease terms. Creating a mortgage over land use rights is theoretically allowed by the Law on Mortgage (article 7.3.). In practice, however, land use rights are not used as collateral because the mentioned provision of the Law on Mortgage has not been regulated and harmonized with other laws on this particular topic.

\section{Unification of all registries related to real (in rem) rights over immovable assets is} expected to be completed by end-2015. After being registered with the Public Notary Office, 
mortgages are currently registered at the Collateral Registry under the Ministry of Justice. Users of the system consider the fees charged by this registry as reasonable: SM 48 (approximately USD 9) for registering a mortgage and SM 20 (approximately US\$3.70) for providing information on a registry file, both flat fees. Obtaining information or registering a mortgage would take 2 days according to the registry authority. The registry is basically paper based, although mortgage agreements are also kept in electronic format. There is no online access to the registry information. It is expected that in 2015 a modern and unified registry under the State Committee on Land will be in charge of registering all the information related to real (in rem) rights over immovable assets, in compliance with the law of the Republic of Tajikistan from March 20, 2008 of No. 375 "About the state registration of real estate and the rights to it."

\section{Enforcement of immovable collateral could be improved by introducing several amendments to the Law on Mortgage and related legislation. Two main issues should be addressed:}

- Out-of-court enforcement of mortgages is not used in practice. The law allows extrajudicial foreclosure on the basis of a notary certified agreement between the mortgagor and the mortgagee, but this agreement should be concluded only after the reasons for foreclosure have arisen. Upon non-performance of the secured obligation, however, it is hard to agree on enforcement mechanisms, so creditors must typically use in-court procedures. Judicial procedures are subject to delay mainly because the debtors may raise objections against all judicial decisions using several recourses (cassation, supervision) established by the procedural legislation. If the high level court revokes a first instance decision, the case is quite usually referred back to the lower level court, which shall issue a new decision-sometimes having to commence the procedure all over again.

- Credit collection through auction sales is quite ineffective. The sale of mortgaged property shall be implemented at a public auction conducted by a court executor ('bailiff'). The court shall define the initial selling price based on the parties' agreement or, otherwise, according to the opinion of an independent expert. If there are no interested buyers, a second auction may be conducted reducing the initial selling price by 15 percent. If this auction also failed - as is usual in practice - the law does not allow a third auction at a further reduced selling price or at no minimum price. Thus, the creditor must purchase the mortgaged property for a price no more than 25 percent below the initial selling price of the first auction (i.e., at least 75 percent of the valuation price), otherwise the mortgage right is cancelled. If the creditor decides to accept the property in payment, the law does not clearly specify how the transfer of ownership should be implemented and how the differences between the creditor's claim amount and the acquisition price should be resolved.

\section{The legal framework governing pledges over movable assets should be urgently}

improved. The use of some assets as collateral is restricted by the law. There are several inconsistencies among the laws that govern pledges -in particular the Law on Pledges, the Civil Code and the Law on Bankruptcy specify priority rankings that are unclear and may be subject to contradictory interpretation. The law establishes out-of-court enforcement for claims secured 
by pledges but in practice most cases end in rather lengthy court proceedings. Although Tajikistan has received in-depth technical assistance, only a very few of the expert recommendations have been adopted in a recently passed reform to the Law on Pledges. None of these amendments will address the deficiencies of the pledge regime, and some could be counterproductive. For example, the new amendments allow out-of-court enforcement "if it is not contrary to the legislation of the Republic of Tajikistan," thus creating uncertainty on the actual applicability of the extrajudicial mechanism defined in the Law on Pledges.

78. At present, the Pledge Registry is a weak institution that is barely used by lenders to register pledge agreements. Because of never fixed deficiencies in the hardware provided to the registry, electronic registration of pledges is no longer available. The few contracts that are submitted to the registry are kept in paper, and all the registry processes are manually implemented -including information searches. The fees charged are not high: SM 28 (about US\$5) for registering a pledge and SM 5 (about US\$1) for providing information on a registry file -flat fees in both cases. Pledge registration and information from the registry would take 2 days. Creditors, however, do not request registration of most pledge contracts -a practice that could create serious priority disputes of uncertain result when multiple pledges are executed over the same collateral. Properly designing and implementing an efficient and reliable registry for security rights and other encumbrances over movable assets is essential to lift the low prestige of movable assets as collateral, and to expand access to credit.

79. The Law on Bankruptcy provides for both liquidation of the insolvent debtor's assets and reorganization/rehabilitation of legal entities and individual entrepreneurs under formal in-court procedures. Consumers (i.e., individuals who do not run any economic or business activity) are not eligible for bankruptcy. State-owned enterprises contemplated in Article 127 of the Civil Code ('Treasury enterprises') are not eligible either. Insolvency proceedings for banks and other financial institutions are regulated by special legislation. Bankruptcy proceedings may be petitioned by the debtor or its creditors.

80. Insolvency is a pre-requisite for starting a bankruptcy case. The law defines insolvency as the debtor's inability to fully satisfy the claims of creditors on monetary obligations and (or) to fulfill the obligation to pay mandatory payments (taxes and other state claims). The debtor shall be deemed unable to satisfy the mentioned claims or payments, if such obligations have not been fulfilled within three months from the due date (cash flow test) and if the total liabilities exceed the value of the debtor's assets (balance sheet test). This double test makes access to bankruptcy proceedings very difficult, and it would be one of the main reasons why creditors do not file bankruptcy petitions more frequently. The law establishes a suspension of enforcement actions ('stay') of unlimited duration that applies to all creditors, including secured claims enforcement. There are no safeguards to protect secured creditor rights in bankruptcy. Further, there are no precedents on how rather unclear provisions governing secured creditors' priority would be interpreted in bankruptcy proceedings. Anticrises managers ('trustees') are neither licensed nor properly supervised by an independent body or agency. 
81. Bankruptcy proceedings are rarely used in Tajikistan. Though in theory the Law on Bankruptcy contains some positive elements, its effectiveness cannot be properly assessed because bankruptcy procedures are extremely rare in practice: less than 10 cases are opened per year in the whole country and all of them end in liquidation. Relevant market players interviewed have never participated in a bankruptcy proceeding. Creditors do not consider bankruptcy proceedings as an option for debt collection. Debtors do not regard bankruptcy as a mechanism for debt resolution or restructuring, let alone for enterprise reorganization. There is a cultural stigma associated with bankruptcy, which is generally regarded as a fraudulent mechanism to evade obligations. It is thus not surprising that successful reorganization/rehabilitation cases are unknown. Further, there is no established practice of parties engaging in consensual agreements outside of formal insolvency proceedings to restore an enterprise financial viability ('workouts'). Business rescue culture is not yet developed.

\section{The legal framework for mortgages ('hypothecs') requires further reforms,} namely: (i) regulating mortgage of land use rights; (ii) allowing out-of-court enforcement mechanisms based on parties' agreements concluded before or after non-performance of secured obligations; and (iii) specifying how the transfer of collateral ownership to the creditor should be implemented after the final auction failed, and how the differences between the creditor's claim amount and the acquisition price should be resolved.

\section{The legal and institutional framework for pledges over movable assets can be} further enhanced by: (i) introducing into the Law on Pledge and related laws amendments agreed in February 2014 by all members of the Working Group led by NBT; and (ii) design and implement a secure, centralized and computerized registry for on-line recording and providing information on all security rights and encumbrances over movable assets.

84. Amendments to the Law on Bankruptcy and related legislation are needed, to: (i) facilitate access to bankruptcy eliminating the insolvency balance sheet test; (ii) establish appropriate safeguards to protect secured claims against collateral depreciation or impairment during bankruptcy; (iii) eliminate inconsistencies in the priority rankings established in the Civil Code, the Law on Pledge, and the Law on Bankruptcy; and (iv) establish an effective procedure for rehabilitating viable businesses in financial distress or insolvency, based on international good practice.

\section{Payment and Settlement Systems}

85. Since the last FSAP, the NBT has initiated a comprehensive structural reform of the national payments system (NPS). Initially system-specific and driven by operational considerations, the NBT reform efforts and plans were later formalized in the national payments system strategy (2015-2025) which was adopted by the NBT Board in October 2014. A medium-term implementation action plan (2015-20) prioritizes: (i) improving the legal and regulatory framework for payment and settlement systems in Tajikistan; and (ii) implementing a new automated transfer system (ATS) to replace the outdated real-time gross settlement (RTGS) system operated by the NBT and to enable interbank clearing of credit transfers and 
direct debits (currently, no automated clearinghouse is available in the country). In 2012, the NBT launched the national card payments switch, thus enabling card payment infrastructure interoperability to a large extent. An oversight division within the payment systems department was established in December 2010; the NBT Law was subsequently amended to provide the legal basis for payment system oversight (in addition to the broad powers to regulate and operate payment and settlement systems).

86. The national economy remains largely cash-based. Limited payments infrastructure is an important constraint: as of end-2014, there were approximately 18.8 point-of-sale (POS) terminals and 8.4 automated teller machines (ATMs, not including cash kiosks) per 100,000 inhabitants. In 2012, there were 7.2 commercial bank branches for every 100,000 adults. These figures are below the regional and income group averages, except for the number of ATMs. With 74 percent of its population living in rural areas, providing access to non-cash payment services has important cost implications. Internet and mobile banking are still incipient. Debit cards have reached 1 million in 2014 (i.e. approximately 130 cards per 1,000 individuals); however, over 90 percent of card transactions (volumes and values) are cash withdrawals.

\section{The draft law on "Payment Services and Payment Systems" is a milestone in the} NPS development: the law should adopt a functional, technology-neutral approach and allow flexibility, minding possible changes in the market going forward. The NBT currently considers the provision of payment services (including e-money) as the privilege of credit institutions. Although this choice is consistent with the Banking Law, the NBT may reassess whether its approach is proportionate to the nature and risk profile of the various types of payment services (e.g. e-money) and evaluate the impact on competition in expanding access to transaction accounts. It is not clear whether non-deposit taking microcredit organizations (MCOs) and microcredit funds would be allowed to issue non cash payment instruments based on the Law on Microfinance Institutions (MFIs), which confines payment services to microcredit deposit-taking organizations (MDOs). Through regulation, the NBT can define preconditions and terms for sustainable interoperability of innovative payment services.

\section{The NBT should continue monitoring the bilateral correspondent banking} relationships for the purposes of settling domestic large-value interbank payments with a view to control and further decrease this practice. The RTGS system is the backbone of the NPS and currently provides settlement services to all commercial banks, most MDOs, and the Treasury of the Ministry of Finance. According to NBT estimates, in 2014 the RTGS system processed 736,000 transactions for a total settled value of SM 76,461.6 million (about US\$16 billion), roughly equal to 1.8 times the total GDP. Although the current RTGS system does not face material credit or liquidity risks-i.e. the RTGS operator does not extend credit to the system's participants and payment orders are rejected immediately upon verification of insufficient funds-banks still rely on bilateral correspondent banking relationships in up to 47.3 percent of the total daily transaction volumes in local currency and 6.2 percent of the transaction value. This practice_-admissible under the current legal framework-represents a 
potential source of settlement risk and inefficiency. The NBT has tightened the regulation around this practice but has not explicitly forbidden it.

89. The NBT should formally adopt a business continuity plan also in light of future ATS implementation; once adopted, the business continuity plan should be tested and regularly reviewed. Although the RTGS system reliability is high, the system does not meet international standards on operational risk management, namely business continuity. Back-up servers are not available at the main site; the secondary site - which is located about ten kilometers from the main site - is not fully equipped. Recovery time is estimated at four hours, but has not been tested. A formal business continuity plan has not been adopted yet. A new, full-fledged secondary site located at about 100 kilometers from the capital Dushanbe is being developed. In the interim, it is important that the NBT intensify controls and procedures for identifying, monitoring, and mitigating all sources of operational risk.

90. Additional, concerted efforts and incentives will be necessary to achieve the targets on non-cash payments and stimulate both demand and supply of non-cash instruments. The NBT established and chairs an inter-institutional committee to identify measures for increasing non-cash payments. An action plan was issued in 2013 which covers legal and regulatory aspects, infrastructure development, awareness, and financial literacy. Among other initiatives, the NBT requires that payment card terminals be installed in all points of sale above 40 square meters, and that cash sales of goods and services at selected locations in the main urban areas be migrated to card payments as of September 1, 2015. Authorities may consider additional actions, including suitable incentives (e.g. tax incentives) to promote private sector investment in infrastructure for electronic retail payments. Agent-based models worldwide have proved successful in addressing gaps in infrastructure and the lack of trust in, or familiarity with, the banking sector. Finally, automated clearinghouse infrastructure is crucial for efficient processing of electronic funds transfers (EFT) products.

\section{Migrant remittances provide Tajikistan with an opportunity to deepen the banking} system and increase access to financial services. In 2014, Tajikistan received about US $\$ 4$ billion in remittances, equivalent to 46 percent of GDP. Remittances are mainly disbursed in cash by commercial banks and to a lesser extent MDOs, each serving as agent of several-local and international-money transfer operators. The cost of sending the equivalent of US\$200 from Russia to Tajikistan is on average 2.2 percent (as of end-2014) as compared to a global average of 8 percent. Payment card infrastructure and other innovative payment mechanisms such as e-money should be leveraged for the disbursement of remittances, and banks should provide recipients with products targeted at low-income segments. A more widespread and cost-efficient coverage of rural areas can be achieved through agent-based models. A more active role of MDOs in this space may be desirable and worth encouraging.

\section{The payment systems oversight function should be strengthened and its scope}

broadened. Since its formal establishment in 2011, the payment system oversight function has been instrumental to NPS strategy development and the reform of the legal framework. However, 
important segments of the payments market remain unattended from an oversight standpoint (e.g., bill collection, international remittances). Sources of risks other than strictly operational risks may fall outside of the payment system overseer's purview (e.g., foreign exchange settlement risk).

\section{Financial Inclusion}

\section{Overview}

93. Tajikistan has one of the lowest levels of financial inclusion in Europe and Central Asia (ECA), and access to financial services remains a major challenge for doing business. According to the Global Financial Inclusion Database (2011) only 2.5 percent of adult population had an account, 0.3 percent saved, and 5 percent had a loan with a formal financial institution. For firms, retained profits are the main source of investment financing which points to inefficient financial intermediation and constrained access to credit. Firms also perceive limited access to credit as an important obstacle for enterprise growth. Tajikistan is served by a very limited network of financial institutions with only 6.7 branches per 100,000 adults, compared to ECA average of 25.4. Some of the most critical obstacles for financial inclusion are lacking longer-term funding in local currency, collateral, and financial infrastructure.

94. The agricultural sector is particularly constrained, and lending to the sector remains limited and expensive. As of 2013, agriculture accounted for 21 percent of GDP and 46.5 percent of employment. However, the share of bank loans to agriculture declined from 55 percent of total outstanding loans in 2009 to 20 percent in 2014.

95. Providing transaction accounts to a greater share of the population would be an important step for greater financial inclusion that requires scaling up the efforts to improve the efficiency and reach of the National Payments System. The analysis and recommendations on this area are included in the financial infrastructure section of this FSA.

96. The most recent developments include the commitment of NBT to the Maya Declaration, the preparation of Microfinance Sector Development Strategy, the adoption of the Law on Islamic Finance, and a privately managed credit guarantee facility that is about to commence operations. As part of the Maya Declaration on financial inclusion, the NBT has committed (by 2017) to develop frameworks for financial consumer protection and education, utilize microfinance to ensure access to financial services for 40 percent of the rural population, and enable delivery of mobile financial services to up to 30 percent of the population. Further, a comprehensive draft Microfinance Sector Development Strategy (201525) has been prepared, and is pending NBT's formal approval and subsequent adoption by the Government. The Law on Islamic Finance was prepared with the support from the Islamic Development Bank and next steps include preparing relevant bylaws and harmonizing the existing legal framework. Finally, development partners from Germany, the Netherlands, and Austria (i.e. DEG, FMO, and OeEB) have invested US\$16 million in a credit guarantee fund 
that is expected to expand client outreach. It will initially work with two microcredit organizations and two commercial banks.

\section{Since 2013, the government has also been providing subsidized lending to enterprises in rural areas through the Fund for Development of Entrepreneurship (FDE);} because of potential distortionary effects, this approach should be reassessed and redesigned. The FDE has disbursed SM 63 million (US\$12 million) to 103 entities in 2013 and 2014 through Amonatbank, which appears to take the credit risk, though it makes no credit decisions, acting on the instructions from the FDE. Additional SM 70 million (US\$13 million) from the state budget is planned for 2015, with the goal of reaching SM 1 billion (US\$186 million) by 2020. The loans are offered for working capital and investment needs with a tenor of 1 to 3 years and fixed interest rate of 12 percent and are secured by collateral. Proceeds matching 1 percentage point of the charged interest rate are placed in a separate fund for potential losses. There have been no issues with portfolio quality thus far. If the government wishes to intervene through the financial sector, it may do so by providing funds on a wholesale basis to eligible financial intermediaries for on-lending to target borrowers, in line with transparent and objective criteria and in a competitive and sustainable fashion, with pricing reflecting costs and risk. Although participating financial intermediaries would bear full credit risk of the borrowers, they would also make credit decisions. The same recommendation would apply to any similar intervention of which the mission may not have been made aware of.

\section{Banking and microfinance sectors}

\section{The banking sector lacks depth, is fairly concentrated, and constrained in} responding to market needs because of lacking longer-term, local-currency funding. The banking sector is small relative to the size of the economy, with assets, loans, and deposits accounting for 30,17, and 14 percent of GDP respectively. The aggregate non-performing loan (NPL) ratio stands above 20 percent. Seven banks have majority foreign ownership, with shareholders from Kazakhstan, Pakistan, Iran, and Turkey, and a few smaller banks with ownership by international financial institutions (e.g. EBRD, IFC). The five largest banks hold 80 percent of total assets, 73 percent of loans, and 86 percent of deposits. Lending to Small and medium enterprises (SMEs) is about 30 percent of total loans, with only a few banks focusing

on this segment. Banks are constrained in responding to market demand for longer term loans in local currency because their liabilities are mostly short-term and in foreign currency. As a result, the average maturity of loans to enterprises is only slightly above one year and over half of all bank lending is in foreign currency.

\section{Efficiency of bank operations is low and spreads remain high. Although the} aggregate net interest margin of 5.4 percent is at par with regional peers (ECA and low income countries), it ranges from -0.6 to 10.5 percent for the six largest banks. A non-interest income to total income of 68 percent, explained by increasing fees and commission revenues and gains from foreign currency trading, is indicative of an unsophisticated market. Profitability has been low in the past five years, and turned significantly negative in the last quarter of 2014 due to 
large provisioning adjustments of AIB. As for efficiency, overhead costs ( 7 percent of total assets) have been increasing and are the highest amongst peer countries. The aggregate cost to income ratio of 66.5 percent is deceiving given the striking differences across the individual banks, ranging from 49 percent to 441 percent just across the six largest banks, according to data received from NBT. Lending interest rates are high in both local and foreign currency, leaving Tajikistan with one of the highest spreads in the region. The decomposition of effective interest spreads shows that they are predominantly driven by overheads and provisions, with profit margins having varying importance across time.

100. The microfinance sector has experienced sustained growth, with the largest institutions competing directly with banks focused on the SME sector; however, it also faces substantial funding constraints, especially in local currency, and limited hedging options. MFOs represent 14.7 percent of the financial system assets with a total active loan portfolio of TJS1.7 billion (US\$316 million) as of October 2014. The NPL ratio in the microfinance sector is around 3.3 percent, while return on assets reached 6.2 percent as of September 2014. The sector is also relatively concentrated, with the five largest MFOs accounting for around 70 percent of total assets. However, the microfinance sector has also expanded significantly in numbers, from 21 institutions serving around 25,000 borrowers in 2005 to 121 institutions serving over 250,000 borrowers in 2014. Although most MFOs serve micro-entrepreneurs, the largest players, which dominate the market, also compete directly with banks in the SME segment with similar interest rates and maturities. Most of MFOs' funding is from external sources because of low deposit mobilization, with over 80 percent in foreign currency due to limited hedging options - about 47 percent of total loans to final borrowers are in foreign currency. The risks of deteriorating portfolio quality are high in light of recent currency depreciation and further pressures.

\section{Financial consumer protection}

101. Only limited progress has been achieved on implementing recommendations of the 2012 Diagnostic Review of Consumer Protection and Financial Literacy; operationalizing the NBT's mandate for financial consumer protection is the immediate priority. The NBT Law was amended in July 2014 providing the NBT with the consumer protection mandate in the banking system. As confirmed by NBT, the interpretation of the term 'banking system' also covers other credit organizations, such as microfinance. However, this provision has not been made operational by dedicating a team or establishing a specialized department tasked with this role. The new department separate from prudential regulation should have a clear mandate, and gradually build its capacity from a smaller team and resources to adequately regulate and supervise financial consumer protection in the medium term. Further, the NBT has issued an instruction (\#199) for MFIs with requirements on effective interest rate and disclosure of information, harmonizing it with requirements for banks (as per instruction \#186). However, no standardized key fact statements have been introduced yet. Most recently, the NBT has opened a hotline for customers who are facing problems with credit institutions, and the NBT supervision department is following up on these complaints. Although this is a positive 
development in the interim, the NBT should address the issue of dispute resolution on a systemic level with clear instructions to financial institutions on handling customer complaints, and identify the most appropriate model for external dispute resolution.

\section{The mandate of NBT on financial consumer protection in banking services could} be extended to all financial services with proportional regulation and oversight. The 2012

Diagnostic Review recommended that the consumer protection authority for insurance products be vested in the insurance regulator - or NBT in case insurance supervision is transferred there-but no progress has been made so far in this area. It is recommended that the government considers extending the mandate of NBT on financial consumer protection to all financial services. The NBT can then developed approach to regulation and oversight of individual services based on the level of risk they could present to financial consumers.

\section{Financial capability}

103. To address issues highlighted in the 2012 Financial Capability and Consumer Protection (FCCP) Survey, it is recommended to develop a financial education strategy. Amongst other, the FCCP survey found that knowledge about services provided by MFIs and commercial banks were known by slightly more than half of the population. The financial education strategy, along with an implementation action plan, should be developed and implemented under the leadership of NBT and in coordination with multiple stakeholders from the government, financial industry, and civil society. The proposed strategy and resulting financial education programs should be based on the financial capability survey, taking in consideration evaluation/lessons learned from any existing, albeit limited, initiatives implemented by NBT, donors (e.g. GIZ) and some financial institutions. It is recommended that the implementation follows a phased approach, utilizing pilots prior to full-scale rollouts, and incorporating impact evaluation mechanisms from the outset.

\section{Financial sector strategy}

104. The current Banking Sector Development Strategy (2010-2015) is expiring, and major stakeholders in financial policy should develop a comprehensive strategy that, among other goals, addresses financial inclusion issues in Tajikistan. The new strategy could be organized along main types of financial services and prioritize those that could have the biggest development impact. Their provision by different types of institutions could then be contemplated with supporting regulatory framework and financial infrastructure. The strategy should also address potential tradeoffs and synergies among financial inclusion, efficiency and stability in provision of prioritized financial services. For example, if savings are considered a priority, the approach should focus on building confidence in the use of these products (e.g. linking remittances with savings), expanding outreach across different sectors (e.g. banking, micro-finance, and capital markets), and mitigating any potential systemic risks associated with expansion of savings products while exploiting synergetic effects on financial stability (e.g. diversification of deposit base) and financial efficiency (e.g. greater volumes available for cheaper financial intermediation due to greater economies of scale). 


\section{E. Insurance Market}

105. The insurance market in Tajikistan is small. For sustainable insurance, economies of scale are as important as the predictability of risk that the law of large numbers provides for suitably sized risk pools. Neither work to the advantage of private insurance in Tajikistan, where the insurance market is small in comparison to its neighbors and local benchmarks, and in comparison to other countries with a similar population size and GDP per capita. Life insurance is particularly underdeveloped and amounts to less than $2 \%$ of total gross insurance premiums. Growth of insurance premiums has not kept pace with GDP growth. Overall premiums in SM fell in 2013 and 2014.

106. The insurance market is also new and unstable. Although Tojiksugurta has been providing insurance to Tajiks since soviet times (when it was the monopoly insurer Tajik Gosstrakh), only one of today's 17 private insurance companies was established before 2004. A typical example of an insurance company from the 2004 generation wrote US $\$ 500,000$ premium in 2014 with a headcount of 15 . Several insurance companies have entered and exited the market in the last five years. Lacking continuity of insurance businesses does not help the industry to establish an image of reliability that is needed to regain the trust of the population.

\section{One reason for the frequent arrival of new insurance companies are lenient}

licensing requirements. The minimum capital requirement is just SM 500,000. There are no comprehensive fit and proper requirements for key personnel, applications for an insurance license do not need to include a business plan or details on risk management and governance, and there is no procedure for how the licensing bodies determine the viability of a new insurance business. The licensing process itself is not clearly regulated. Although the current insurance law states that it is the responsibility of the insurance supervisor, licensing of insurance companies is de facto decided by a commission in which the insurance supervisor is only one member. Another reason for the establishment of new insurance companies appears to be the desire of banks to retain control over (and profits from) the insurance of the assets taken as the collateral for loans.

108. The insurance sector is highly concentrated, both in providers and in products. The 15 types of mandatory insurance can only be underwritten by the two state owned insurance companies Tajiksugurta and Tajiksarmoyaguzor, who together had a share of 62 percent of market premiums in 2014, up from 33 percent in 2006. For many of these mandatory insurances, this monopoly does not distort the market substantially. But Tajiksugurta's monopoly on Motor Third Party Liability (MTPL) insurance does distort the market, and has far reaching consequences. First, excluding private insurers from this substantial line of business (which accounted for a third of total market premiums in 2014) limits their portfolio diversification and revenue potential, thus limiting their capacity to invest in human and IT resources. Second, excluding private insurers from MTPL denies them access to the most important line of retail insurance, limiting their possibility to establish relationship with households. Third, the image of the insurance industry is determined by car insurance, and the 
image is currently not favorable. This affects every insurance company, but private insurers cannot do anything about it while MTPL remains a monopoly.

109. There are good reasons to end the monopoly of key lines of insurance business, but it comes at a cost. As the SOE's monopoly on mandatory insurance is not scheduled in Tajikistan's WTO commitment, it may potentially raise questions regarding the compatibility of this practice with WTO commitments, requiring changes of the law to remove market access barriers. But 70 percent of the state insurance profits revert to the MoF, amounting to 19 million SM for Tajiksugurta alone in 2014. By contrast, income tax revenue from private insurance companies is negligible. Given its unique position in the market, Tajiksugurta is the main source of capacity transfer, as many private insurers are managed by former employees of Tajiksugurta, which is also a main source of staffing for the supervisor. There are no restrictions on foreign ownership of insurers, but only one company has foreign capital.

110. The lack of product diversification affects life insurance in particular. In addition to the benefits to individuals and insurers, a well-developed life insurance market usually contributes considerably to capital markets development and government financing through the purchase of and investment in government bonds; the lack of government bonds in Tajikistan limits the investment options for any life insurance. The most important reason why life insurance is in low demand today is the experience of two massive currency devaluations in 1995 and 2000, which eroded the value of the significant numbers of life insurance policies that were appreciated considerably by Tajiks during soviet times.

\section{Tajikistan's current insurance law is not consistent with the requirements of a} number of Insurance Core Principles (ICPs). The International Association of Insurance Supervisors has issued ICP that provide a globally accepted framework to maintain a fair, safe, and stable insurance sector for the benefit and protection of the interests of policyholders, beneficiaries and claimants, as well as to contribute to the stability of the financial system. Tajikistan's current insurance law is not consistent with the requirements of a number of ICPs, for example those on the independence and powers of the insurance supervisor. A new draft insurance law that is more consistent with the ICPs is currently discussed with the industry. It is expected to eliminate some monopolies, and to be implemented in 2015. A separate draft law on MTPL that will regulate the market's access and conduct is at an earlier stage of review.

\section{The high concentration in a small and imperfectly regulated market has several implications that can present obstacles to the development of insurance in Tajikistan:}

- Most insurers are very small. Their economies of scale imply scant resources for anything from branding and marketing, to technology and administrative processes, to needs assessment and product development. They have scarce access to international reinsurance, no financial or technical capacity to underwrite major risks, and are not positioned to participate in lines like MTPL or agriculture insurance once the monopolies fall without the statistics of past claims experience. Furthermore, the low economies of scale prevent many from providing products with high enough payout ratios to constitute reasonable customer 
value. Their small risk pool sizes make them vulnerable to adverse underwriting deviations which their small capital base and unaudited reserves will struggle to sustain.

- The insurance industry does not generate enough surplus to endow its supervisor with the resources that would ideally be needed to create a level playing field and enabling environment that promotes growth, stability and client value. Considerably lower salaries at the supervisor (as compared to what similarly qualified staff of insurance companies earns) make it difficult to attract and retain suitably skilled professionals, and lacking training budgets challenge the development and maintenance of expertise. The supervisor is not equipped to promote an enabling and competitive environment, such as transparency and trust (through the publication of suitably compiled, formatted, analyzed and explained data), consumer protection and advocacy, dispute resolution, codes of conduct, and insurance education.

- The market lacks enabling infrastructure. There are no actuaries, and no training curriculum in place yet to qualify Tajiks as actuaries, underwriters or loss adjustors. There are no market wide claims databases or other mechanisms designed to prevent insurance fraud. This is explained in part by the absence of an insurance association, which could help to provide such public goods and work to increase awareness, understanding and trust for insurance in the population, while addressing common issues from the regulatory framework to tax treatment in a coordinated fashion.

- The experience with the design of modern regulatory frameworks is limited in Tajikistan. Although the World Bank has provided significant technical assistance in drafting of the insurance law, various by-laws, subsidiary regulation, norms and guidance will need to be implemented to regulate MTPL and other compulsory insurances.

\section{The future of an independent insurance supervisor should be clarified as soon as} possible. As the industry is currently too small to support a meaningful supervision by itself through fees, establishing the State Insurance Supervisory Service (SISS) as a department within the National Bank of Tajikistan would be the preferred alternative and would have significant advantages. This had been included in a 36 point action plan prepared by the investment council and scheduled for 2015, so there is expectation of change in the market.

\section{Implementation of the new insurance law (including the removal of monopolies)}

should be expedited. This is also a key component of the 13 point action plan, and the law has been prepared with considerable technical assistance. The action plan anticipates

implementation of a new law on insurance activities as well as new by-laws for MTPL, agriculture and other compulsory insurances by 2016. Every effort should be made to achieve this objective soon, so as to remove the current uncertainty.

\section{The mandate of SISS should be extended to have a development objective in} addition to its prudential objective. Thus, SISS should provide necessary public goods such as disclosure of insurers' financial information, consumer protection and dispute resolution, 
capacity building strategies, and awareness campaigns. It should also revise and strengthen the market entry requirements.

\section{Microfinance organizations should be allowed to act as agents for insurance} companies to increase penetration of insurance among the population. This will be an important first step toward the innovation in insurance distribution that is characteristic of inclusive insurance markets. Insurance will have to develop strategies to serve more people also outside of Dushanbe. Given the challenging geography, this will require adopting novel distribution and service partnerships, which in many countries have also helped reduce operating cost and made insurance affordable for those who were previously considered uninsurable due to their low income. This approach is referred to as microinsurance, and the many lessons from other countries can help Tajikistan speed up its development. 
Figure 1. Tajikistan: Macroeconomic Developments
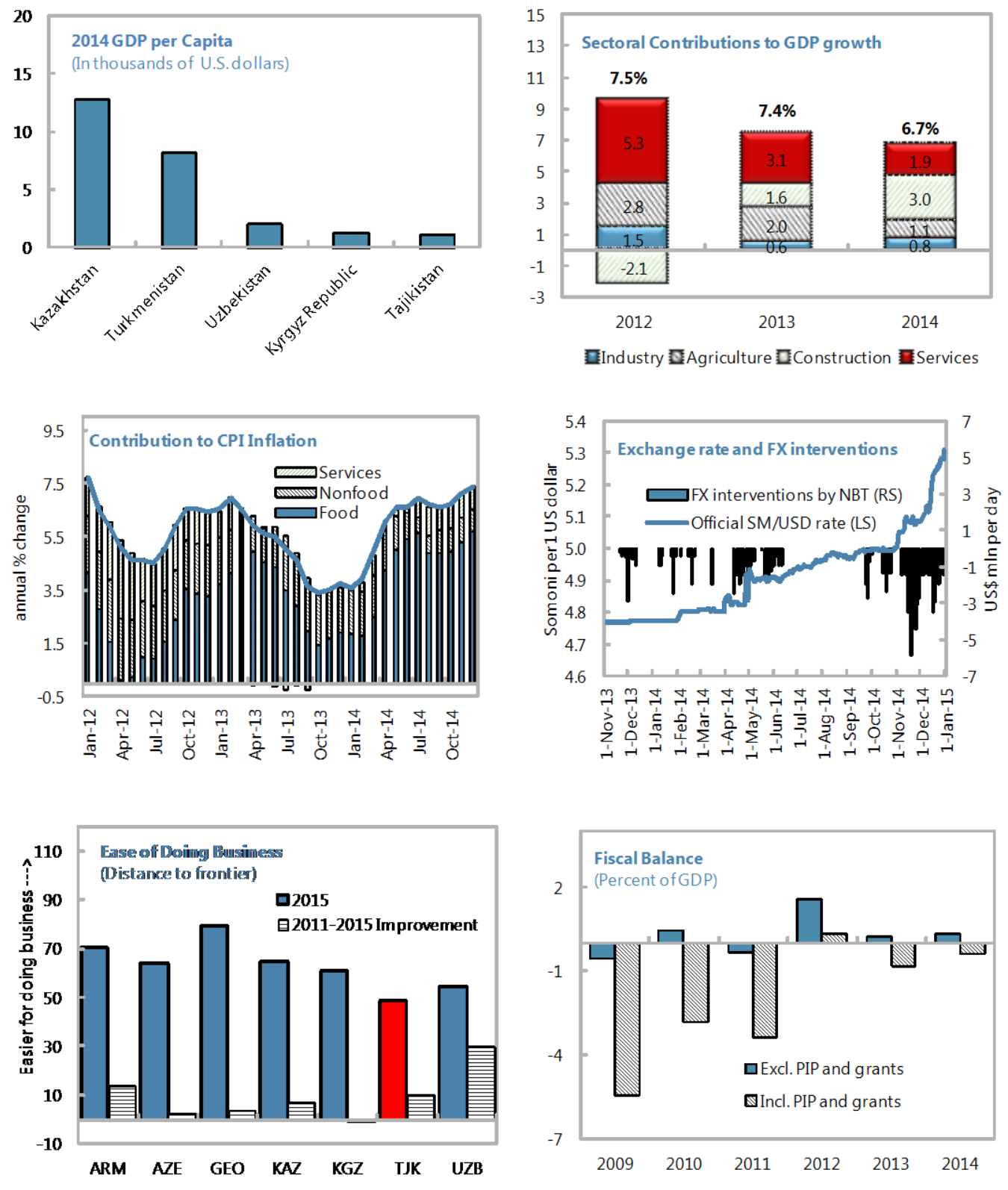

Sources: NBT, WEO, and ; World Bank Doing Business (2015), IMF staff calculations 
Figure 2. Tajikistan: Macroeconomic Vulnerabilities
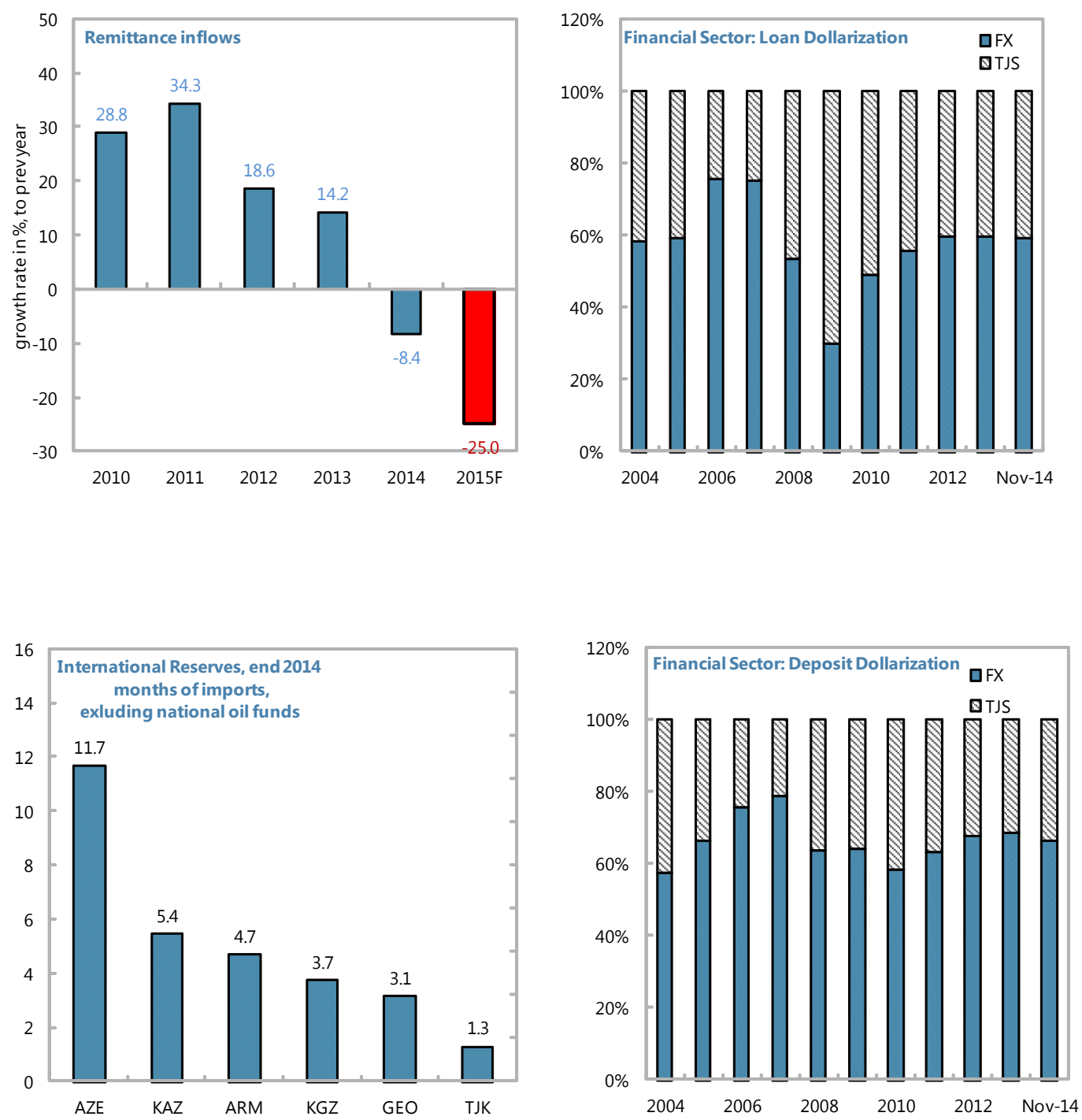


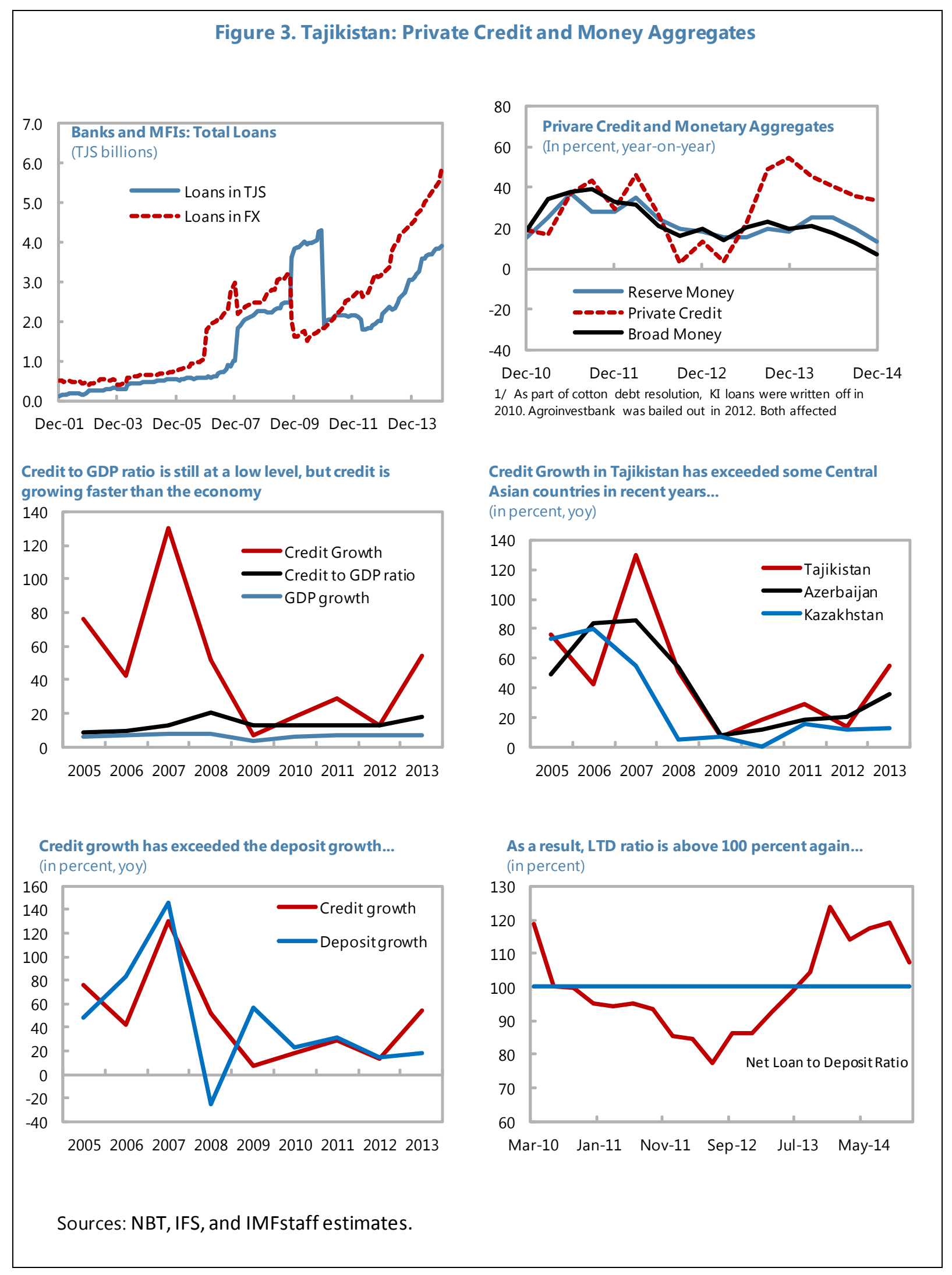


Figure 4. Tajikistan: Bank Loans and NPLs Concentration by Economic Sector
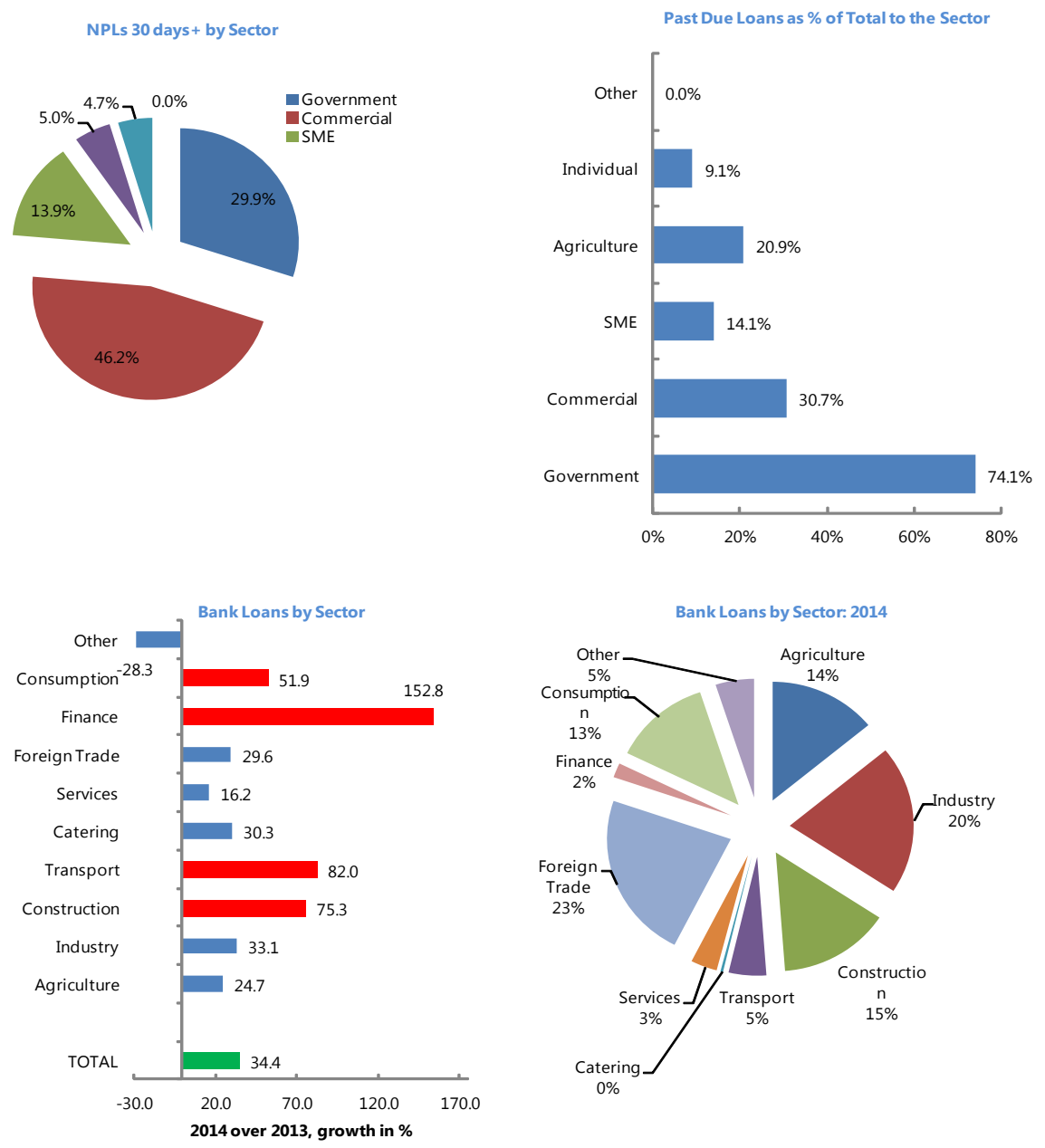

Sources:NBT, IFS; and IMF staff estimates. 


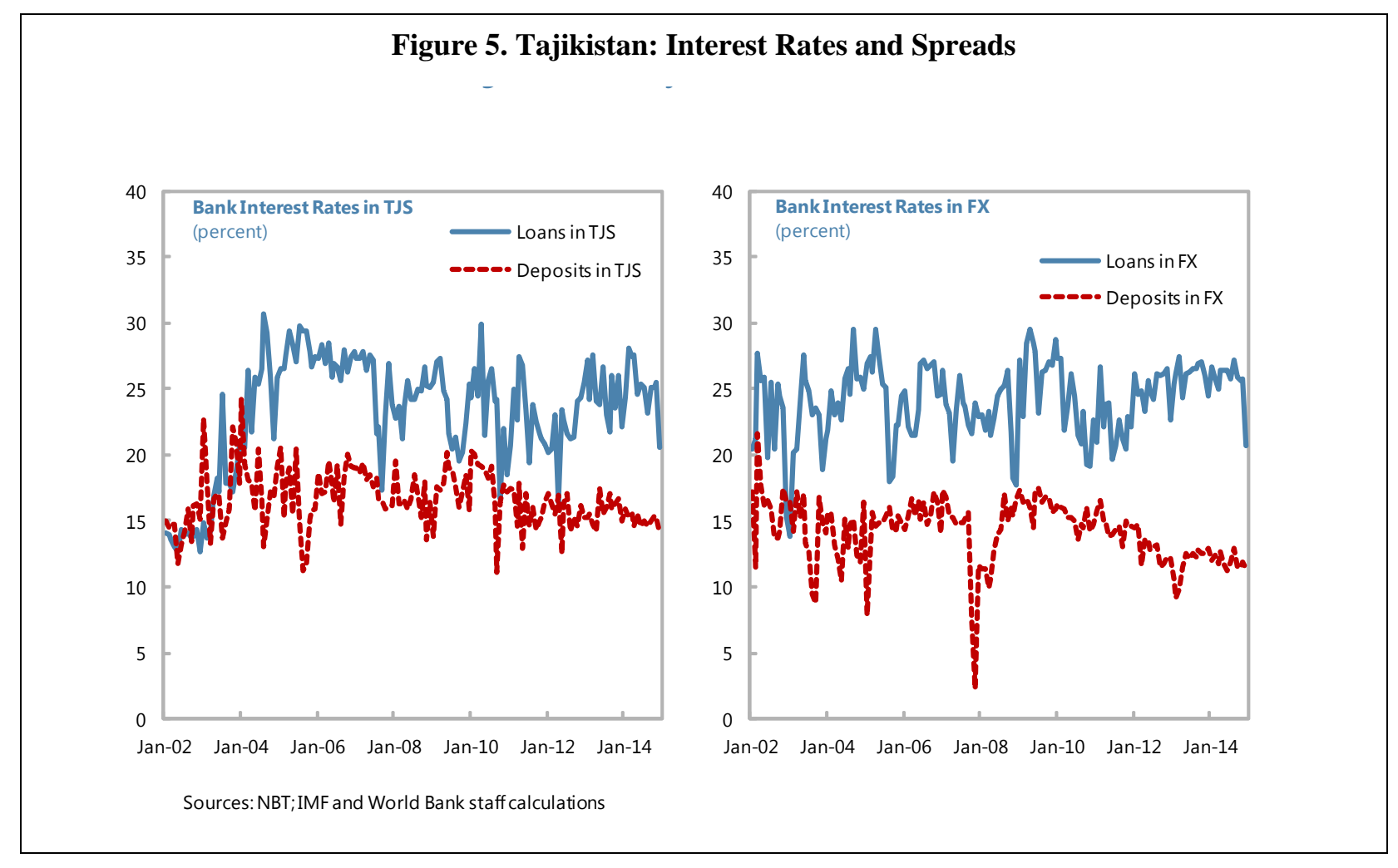


Table 3. Tajikistan: Status of 2007 FSAP Main Recommendations

\begin{tabular}{|c|c|}
\hline dations & Actions Taken \\
\hline & \\
\hline $\begin{array}{l}\text { Strengthen the surveillance framework to monitor } \\
\text { the build-up of credit risk in the banking system to } \\
\text { ensure that problems, if and when they emerge, can } \\
\text { be addressed promptly. }\end{array}$ & $\begin{array}{l}\text { Partially done. The NBT has issued a confidential internal guidance document } \\
\text { on an improved CAMEL-based supervisory bank rating methodology. The part } \\
\text { of this guidance that addresses asset quality comprises } 25 \text { assessment } \\
\text { parameters. The Law on NBT, in Art. } 48 \text {, enumerates a wide range of } \\
\text { corrective measures including compliance orders, instructions, corrective action } \\
\text { plans, cease and desist orders, restrictions on dividend payments, financial } \\
\text { rehabilitation, structural reorganization, fines, tighter prudential standards for } \\
\text { the institution involved, recapitalization by shareholders, revocation of the } \\
\text { license. In practice, however, regulatory forbearance is still provided, corrective } \\
\text { measures are often not used promptly or if used are not commensurate to the } \\
\text { emerging risks. }\end{array}$ \\
\hline $\begin{array}{l}\text { Develop and implement a strategy for the } \\
\text { resolution of cotton debt. Key first steps should be } \\
\text { an immediate halt to KI's non-asset-management- } \\
\text { related commercial activities, followed by its } \\
\text { comprehensive due diligence audit. KI may need to } \\
\text { be resolved in the context of a comprehensive plan } \\
\text { for the cotton sector. }\end{array}$ & $\begin{array}{l}\text { Done. Cotton debt resolution strategy was developed and cotton debt was } \\
\text { resolved. Kredit-Invest went through a due diligence audit and was resolved } \\
\text { and closed down in } 2012 \text {. As part of the strategy, cotton investors' debt } \\
\text { amounting to } \$ 154 \text { million was transferred to the NBT to be collected over } \\
2010-2018 \text { according to an approved schedule. As of January } 2015 \text {, NBT } \\
\text { managed to recover just } 0.015 \text { million US dollars, undermining the original } \\
\text { NBT recapitalization strategy and requiring additional contributions from the } \\
\text { Ministry of Finance to replenish NBT's negative capital. }\end{array}$ \\
\hline $\begin{array}{l}\text { Strengthen the governance and autonomy of the } \\
\text { NBT. In particular, rules for the appointment, } \\
\text { dismissal, and terms of office for the Chairman and } \\
\text { the Board members should be spelled out, and clear } \\
\text { provisions on conflicts of interest should be } \\
\text { introduced in the law. }\end{array}$ & $\begin{array}{l}\text { Done, Art. } 74 \text { of the Law on The National Bank of Tajikistan (amended June } \\
\text { 2011) (LNBT) states that the chairman, deputy chairman and independent } \\
\text { Board members of the NBT shall be appointed by presidential decree, approved } \\
\text { by parliament, for terms of respectively seven, five and four years. Art. } 75 \\
\text { gives a limitative enumeration of the grounds for dismissal of these persons. } \\
\text { Art. } 78 \text { (2) states that these persons must declare personal commercial financial } \\
\text { or other interests to the Board if an issue considered by the Board affects these } \\
\text { interests; these persons are barred from voting on these issues. }\end{array}$ \\
\hline $\begin{array}{l}\text { The NBT should be recapitalized, including } \\
\text { through the securitization of the government debt it } \\
\text { holds. Further, the NBT must not resume } \\
\text { commercial lending operations. }\end{array}$ & $\begin{array}{l}\text { Partially done. Recapitalization of the NBT proceeded as scheduled through } \\
\text { 2013. In 2014, the MOF contributed only } 61 \text { million SM, about half of the } \\
\text { required annual contribution of } 120 \text { million SM envisaged under the plan and } \\
\text { approved by Presidential edict. The NBT no longer lends to the private sector } \\
\text { and liquidity lending is priced at a } 200 \text { basis points penalty above average } \\
\text { interbank market rates. }\end{array}$ \\
\hline $\begin{array}{l}\text { Strengthen the legal framework for bank licensing } \\
\text { by reintroducing legal provisions on the NBT's } \\
\text { authority to license banks, and allow the NBT to }\end{array}$ & $\begin{array}{l}\text { Partially done. Art. } 6 \text { LNBT (1) ( } 3 \mathrm{~d} \text { indent) states as one of the objectives of the } \\
\text { NBT the issuing of licenses to lending institutions and the regulation and } \\
\text { supervision of their activities. Moreover, Art. } 42 \text { (1) first indent states that the }\end{array}$ \\
\hline
\end{tabular}




\begin{tabular}{|c|c|}
\hline Recommendations & Actions Taken \\
\hline $\begin{array}{l}\text { check on the suitability of beneficial owners of } \\
\text { banks. }\end{array}$ & $\begin{array}{l}\text { NBT has the exclusive right to supervise banks and, to that end, shall issue } \\
\text { bank licenses. Art. } 7 \text { of the Law on Banking Activities (May 2009) (LBA) also } \\
\text { states that a license shall be issued by the NBT. Persons with a share, or with } \\
\text { the ability to exercise voting rights, of } 10 \text { percent or more, directly or as an } \\
\text { ultimate beneficial owner, are considered to have a qualifying holding (Art. 1, } \\
\text { indent 20) and must be approved by the NBT as a bank shareholder in the } \\
\text { licensing process. Art. } 9 \text { LBA states that such persons must submit personal } \\
\text { information, as well as information on business profession and financial } \\
\text { standing, and declare in writing that they have not been convicted in a court of } \\
\text { law, bankruptcy has not been filed, and they have not been subject to } \\
\text { professional restrictions. They must declare the identity of shareholders in any } \\
\text { of their business enterprises. The NBT may request additional information. Art. } \\
\text { 10 (7), second and third indent, states that the NBT must be satisfied as to the } \\
\text { satisfactory financial situation and activities of shareholders and as to the } \\
\text { identity and character of qualifying holders and executives as fit and proper } \\
\text { persons. Misleading or fraudulent information is a ground for withdrawal of the } \\
\text { license (Art. } 18 \text { LBA). Acquisition of a qualifying holding in an existing bank } \\
\text { is subject to a similar approval process (Art. } 26 \text { LBA). NBT has also drafted a } \\
\text { Guidance On Information Disclosure by Banks allowing checking the } \\
\text { suitability of banks' beneficial owners. The Guidance was approved by NBT } \\
\text { Resolution } 91 \text { in May } 2014 \text {, but is not registered with Ministry of Justice yet. }\end{array}$ \\
\hline Implement AML/CFT preventive measures. & $\begin{array}{l}\text { Done. Law Against Money-laundering and Financing of Terrorism was adopted } \\
\text { in March } 2011 \text {. All relevant laws and regulations are posted on the NBT } \\
\text { website, under "Financial Monitoring Department." Articles } 262 \text { and } 179 \text { of the } \\
\text { Criminal Code designate respectively money laundering (ML) and the } \\
\text { financing of terrorism (FT) as criminal offenses. Obligations to report } \\
\text { suspected money laundering (ML) or financing of terrorism (FT) have been } \\
\text { imposed on a broad range of persons and agencies, including lawyers and } \\
\text { public notaries. The criminal code identifies over } 100 \text { offenses as predicate } \\
\text { offenses which can give rise to money laundering. Between } 2008 \text { and } 2014 \text { a } \\
\text { broad range of anti- ML instructions, rules and regulations have been issued, } \\
\text { including Instruction } 200 \text { on KYC, Regulation } 87 \text { on freezing of funds, } \\
\text { Resolution } 87 \text { on indicators for suspicious transactions, Instruction } 181 \text { (Art. } \\
\text { 27) on Risk Management and Internal Controls, and Instruction } 171 \text { (Art. } 30 \text { ) } \\
\text { on Opening a Bank Account, and Circular } 306 \text { providing Guidance for Credit } \\
\text { Organizations in Detecting Terrorist Financing Activities. Reporting of } \\
\text { suspicious transactions to the FIU can be done online, through special protected } \\
\text { software introduced in March 2013. In light of significant progress in } \\
\text { improving its AML/CFT regime, Tajikistan exited the Financial Action Task } \\
\text { Force's (FATF) International Cooperation Review Group monitoring process in } \\
\text { October } 2014 \text {. }\end{array}$ \\
\hline
\end{tabular}




\begin{tabular}{|c|c|}
\hline Recommendations & Actions Taken \\
\hline $\begin{array}{l}\text { Launch a program of issuance of government } \\
\text { securities, which would help develop the bond } \\
\text { market and strengthen NBT's monetary framework. }\end{array}$ & $\begin{array}{l}\text { Done. Program of government securities issuance was formally launched, but } \\
\text { the market remains dormant and volumes of Treasury bills issuance are tiny. } \\
\text { There is no serious interest by the MOF to further develop government bond } \\
\text { market. In contrast, the NBT bills auctions and issuance work well. }\end{array}$ \\
\hline $\begin{array}{l}\text { Continue strengthening the bank regulatory and } \\
\text { supervisory framework, including by submitting } \\
\text { public banks to annual independent external audits. }\end{array}$ & $\begin{array}{l}\text { Partially done. Since the } 2007 \text { FSAP a broad range of legislative and regulatory } \\
\text { changes have been introduced to strengthen the bank regulatory and } \\
\text { supervisory framework, including a new Law on the National Bank of } \\
\text { Tajikistan (2011), a new Law on Banking Activities (2009), A Law on the } \\
\text { Liquidation of lending Institutions ( } 2011 \text { ), Instruction } 176 \text { (amended 2014) on } \\
\text { capital adequacy, liquidity, connected lending, and other key prudential ratios, } \\
\text { Instruction } 186 \text { (amended 2014) on banks' credit policies including dealing } \\
\text { with bad loans, Instruction } 177 \text { (amended 2014) on loan classification and } \\
\text { provisioning, Instruction } 181 \text { (2011), on risk management and internal controls. } \\
\text { Articles } 43 \text { and } 44 \text { of the LBA state that all banks shall prepare and publish } \\
\text { audited annual financial statements. Draft regulations have been prepared on } \\
\text { remedial action against banks based on the CAMEL (Sensitivity to market risk } \\
\text { is not covered) methodology, on bank licensing and on supervision on a } \\
\text { consolidated basis. Overall, bank regulatory and supervisory framework was } \\
\text { strengthened, but in practice significant slippages such as prudential } \\
\text { forbearance remain. }\end{array}$ \\
\hline \multicolumn{2}{|l|}{ Medium-term } \\
\hline $\begin{array}{l}\text { Eliminate the monopoly privileges of state-owned } \\
\text { insurance companies on compulsory insurance } \\
\text { products. }\end{array}$ & Not done. \\
\hline $\begin{array}{l}\text { Bring the new draft laws on insurance, deposit } \\
\text { insurance, and credit bureaus into line with } \\
\text { international good practice and submit them to } \\
\text { parliament. }\end{array}$ & $\begin{array}{l}\text { Partially done. The Law On Deposit Insurance of Individual Savings (2011, } \\
\text { new edition) and the Law on Credit Histories (2009) were adopted and are } \\
\text { largely aligned with good international practice, The new edition of Law on } \\
\text { Insurance is still pending. }\end{array}$ \\
\hline $\begin{array}{l}\text { Ensure the business continuity of the real time } \\
\text { gross settlement (RTGS) system and progressively } \\
\text { migrate all large-value domestic currency payments } \\
\text { from bilateral correspondent accounts to the RTGS. }\end{array}$ & $\begin{array}{l}\text { Partially done. The NBT plans to purchase and set up an up-to-date and } \\
\text { automated interbank money transfer system to replace the interbank payments } \\
\text { system that it currently uses in } 2015-2016 \text {. The purchase of this system will be } \\
\text { made possible by a grant from the World Bank called "Enhancing the } \\
\text { Competiveness of the Private Sector." The new system will be equipped with } \\
\text { reliable tools for managing risks associated with payments, such as a tool for } \\
\text { managing the timeliness of payments and the capacity to handle overnight and } \\
\text { one-day loans from members. It is envisaged that after new system becomes } \\
\text { operational, credit institutions will migrate all large-value domestic payments } \\
\text { from bilateral correspondent accounts to the new RTGS. }\end{array}$ \\
\hline
\end{tabular}


Table 4. Tajikistan: Selected Economic Indicators, 2011-2020

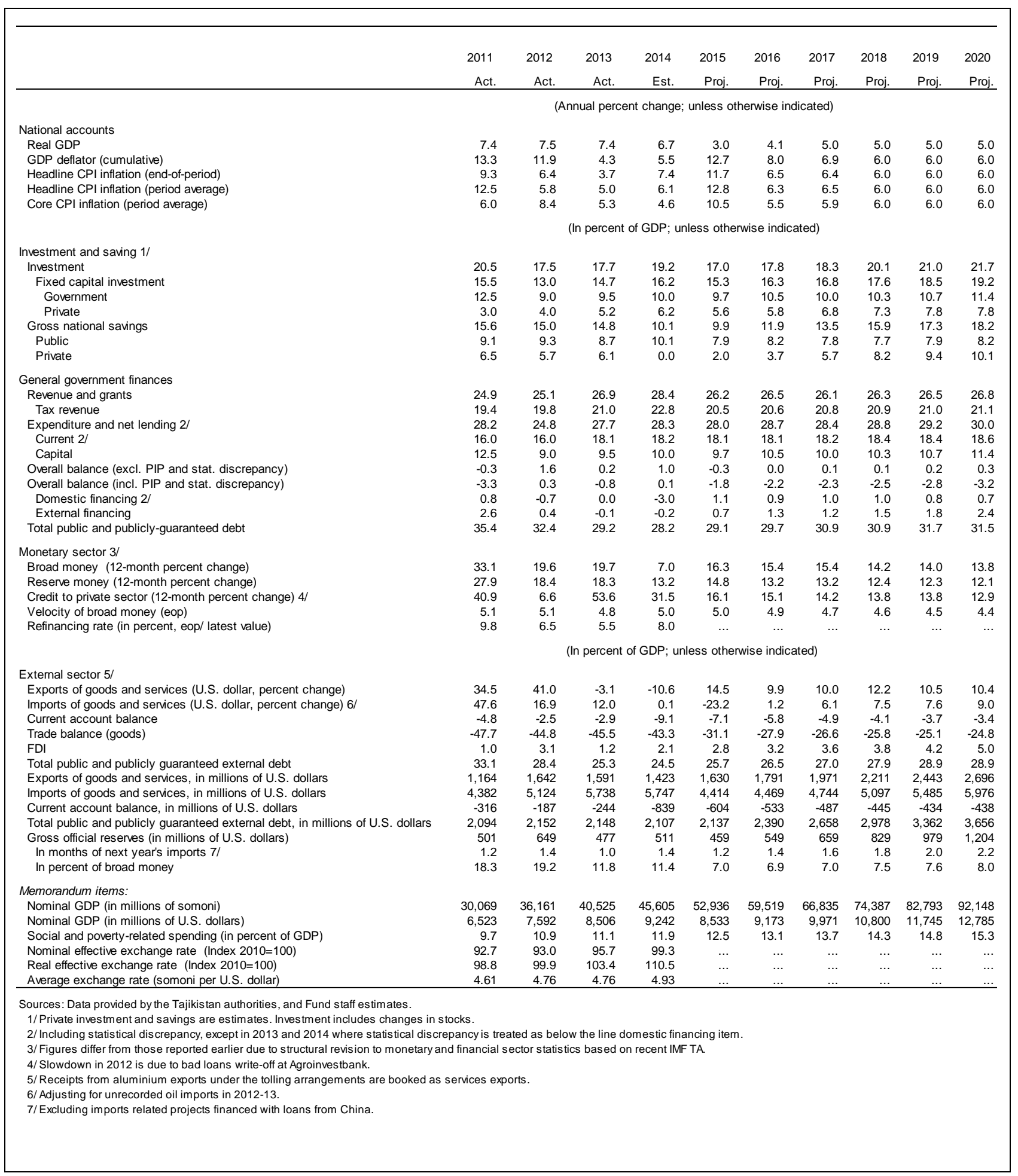


Table 5. Tajikistan: Financial Soundness Indicators, 2010-14 1/

(In percent, unless specified)

\begin{tabular}{|c|c|c|c|c|c|c|}
\hline & Dec-10 & Dec-11 & Dec-12 & Dec-13 & Sep-14 & Dec-14 \\
\hline \multicolumn{7}{|l|}{ Solvency Indicators } \\
\hline Regulatory Tier 1 Capital to Risk-Weighted Assets & 24.5 & 21.2 & 23.3 & 20.6 & 19.1 & 12.0 \\
\hline Regulatory Capital to Risk-Weighted Assets & 26.6 & 24.4 & 25.9 & 22.5 & 20.2 & 14.7 \\
\hline Capital to Assets & 18.9 & 19.3 & 20.5 & 19.0 & 17.3 & 13.2 \\
\hline \multicolumn{7}{|l|}{ Liquidity Indicators } \\
\hline Liquid Assets to Total Assets (Liquid Asset Ratio) & 26.0 & 24.5 & 30.0 & 23.8 & 24.7 & 21.5 \\
\hline Liquid Assets to Short Term Liabilities & 62.5 & 65.1 & 83.7 & 79.7 & 86.1 & 71.4 \\
\hline Deposits to Total Assets (excluding interbank deposits) & 48.7 & 50.6 & 50.2 & 47.8 & 42.9 & 49.6 \\
\hline Loans to Deposits & 101.6 & 95.1 & 94.1 & 117.2 & 128.7 & 126.7 \\
\hline \multicolumn{7}{|c|}{ Sectoral distribution of bank credit to the private sector in percent of total credit to private sector } \\
\hline Public & 9.7 & 7.6 & 16.5 & 15.4 & 10.8 & 10.9 \\
\hline Commerce & 46.9 & 48.4 & 34.2 & 38.1 & 41.0 & 36.7 \\
\hline SME & 0.0 & 25.8 & 27.8 & 26.6 & 27.9 & 29.6 \\
\hline Agriculture & 13.8 & 10.7 & 11.9 & 7.4 & 6.0 & 6.7 \\
\hline Consumer & 29.4 & 7.6 & 9.5 & 12.5 & 14.3 & 16.0 \\
\hline Other & 0.2 & 0.0 & 0.1 & 0.0 & 0.0 & 0.0 \\
\hline \multicolumn{7}{|l|}{ Asset Quality } \\
\hline Non-performing Loans to Total Gross Loans 1/ & 17.2 & 14.1 & 18.2 & 22.9 & 25.4 & 27.2 \\
\hline Provisions to Non-performing Loans $1 /$ & 36.0 & 45.0 & 43.5 & 34.7 & 29.1 & 56.7 \\
\hline Non-performing Loans Net of Provisions to Capital $1 /$ & 28.8 & 19.3 & 23.7 & 44.5 & 57.6 & 56.2 \\
\hline Non-performing Loans to Total Gross Loans 2/ & 7.5 & 7.2 & 9.5 & 16.0 & 22.0 & 25.1 \\
\hline Provisions to Non-performing Loans 2/ & 73.7 & 80.5 & 75.6 & 46.4 & 32.8 & 60.8 \\
\hline Non-performing Loans Net of Provisions to Capital 2/ & 5.2 & 3.5 & 5.3 & 25.5 & 47.4 & 46.9 \\
\hline Large Exposures to Capital & 62.9 & 68.1 & 58.5 & 90.4 & 90.3 & 103.2 \\
\hline \multicolumn{7}{|l|}{ Profitability Indicators } \\
\hline Return on Assets & 0.7 & -0.4 & 0.2 & 0.7 & 1.9 & -5.0 \\
\hline Return on Equity 2/ & 3.6 & -2.3 & 0.7 & 3.8 & 10.9 & -29.6 \\
\hline Interest Margin to Gross Income & 50.5 & 46.4 & 33.2 & 40.4 & 35.0 & 32.0 \\
\hline Non-interest Expenses to Gross Income & 62.4 & 86.2 & 75.8 & 65.9 & 62.2 & 66.5 \\
\hline Personnel Expenses to Non-interest Expense & 55.0 & 54.4 & 50.8 & 55.5 & 54.8 & 53.2 \\
\hline \multicolumn{7}{|l|}{ Foreign Exchange Risk Indicators } \\
\hline Net Open Position in Foreign Exchange to Capital & -0.3 & -3.1 & -0.7 & 2.3 & -0.7 & 0.8 \\
\hline Foreign-Currency-Denominated Loans to Total Loans & 54.1 & 61.2 & 65.2 & 60.7 & 57.8 & 54.1 \\
\hline Foreign-Currency-Denominated Liabilities to Total Liabilities & 55.5 & 58.1 & 62.9 & 59.4 & 59.3 & 64.5 \\
\hline \multicolumn{7}{|c|}{$\begin{array}{l}\text { Sources: National Bank of Tajikistan. } \\
\text { 1/Nonperforming loans include } 4 \text { loan classifications: substandard (1-30 days past due), doubtful (30-60), problem } \\
(60-180) \text {, and bad ( } 180 \text { days }+) \text {. }\end{array}$} \\
\hline \multicolumn{7}{|c|}{ 2/ Nonperforming loans include 3 loan classifications: doubtful (30-60), problem (60-180), and bad( 180 days +). } \\
\hline
\end{tabular}

